\title{
Advance Data
}

\section{Measuring HIV risk in the U.S. population aged 15-44: Results from Cycle 6 of the National Survey of Family Growth}

\author{
By John E. Anderson, Ph.D., National Center for HIV, STD, and TB Prevention; William D. Mosher, Ph.D., \\ and Anjani Chandra, Ph.D., National Center for Health Statistics
}

\section{Abstract}

Objective-This report presents national estimates of the percentage and number of persons in the U.S. population aged 15-44 who report behaviors that place them at increased risk for acquiring or transmitting human immunodeficiency virus, or HIV. The report also contains data on condom use and HIV testing by persons who report risk behaviors. In addition, estimates of self-reported risk for HIV from the Cycle 6 National Survey of Family Growth (NSFG) are compared with data from other recent national surveys.

Methods-Data from the NSFG Cycle 6, conducted by the Centers for Disease Control and Prevention's (CDC) National Center for Health Statistics (NCHS), are based on interviews with a national sample of the household population of the United States. In-person, face-to-face interviews were conducted in the homes of 12,571 males and females 15-44 years of age in 2002. Most of the data were collected by ComputerAssisted Personal Interviewing (CAPI), in which a laptop computer is used to select and present the questions, which an interviewer reads to the respondent. The more sensitive data, including the risk behavior items on which this report is based, were collected by Audio Computer-Assisted Self-Interviewing (ACASI), in which the respondent listens to a recording of each question and enters his or her own answers into the computer without involving an interviewer.

Results - Overall, 8.9 percent of persons 15-44 years of age had engaged in sexual behaviors in the past year that put them at increased risk of HIV, and 1.5 percent had engaged in drug use behaviors that put them at risk. In all, an estimated 9.9 percent engaged in either drug use or sexual behavior that placed them at increased risk for HIV. Including those who were treated for a sexually transmitted disease (STD) in the past year, 11.9 percent of persons 15-44 years of age- 13.0 percent males and 10.8 percent of females-were at risk of HIV in 2002. The 11.9 percent at risk is equivalent to an estimated 14.4 million persons aged 15-44 at higher risk of HIV through drug use, sexual behavior, or having been treated for an STD in the past year. Persons who were at increased risk reported greater condom use and higher rates of HIV testing, but among those at risk, 33.6 percent had never been tested for HIV and 60.4 percent did not use condoms at last sex.

Keywords: HIV • HIV risk behavior • HIV testing • National Survey of Family Growth

\section{Overview}

This report is intended to provide reliable national estimates of some basic statistics on certain types of sexual and drug use behavior, in order to estimate the size and characteristics of populations at elevated risk for acquiring or transmitting human immunodeficiency virus or HIV, the virus that causes acquired immunodeficiency syndrome (AIDS). The approach follows previous survey analyses in classifying persons by whether they report behaviors that have been found to be closely linked to transmission of HIV in epidemiologic studies $(1,2)$. The data used for this report are from the National Survey of Family Growth (NSFG) conducted in 2002 , the sixth in a series of national reproductive health surveys that have been conducted since 1973. The survey was based on in-person interviews conducted between March 2002 and March 2003 in the homes of 12,571 people (4,928 men and 7,643 women) 15-44 years of age in the household population of the United States. The response rate for the survey was 79 percent. The demographic characteristics used in this report were collected by an interviewer, but the 
measures of drug and sexual behavior reported here were collected in the self-administered portion of the Cycle 6 NSFG survey in which respondents read the questions (or heard them through headphones) and entered their own answers into a laptop computer, thus ensuring their privacy. Tables A-D are summary tables embedded within the text, and Tables 1-10, which provide greater detail on these topics, are shown at the end of the text.

\section{Highlights}

- Among males and females 15-44 years of age, 8.9 percent were at risk of HIV because of their sexual behavior in the last 12 months. As defined for this report, persons at "behavioral risk of HIV" include those who had five or more oppositesex partners in the last year, persons who had sex with an injecting drug user, persons who had sex with an HIV-infected person, those who exchanged sex for money or drugs, men who had sex with other men, and women who had sex with a man who has sex with men (Table A).

- Drug-related risk in the past year (illicit drug injection or use of crack cocaine) put 1.5 percent at risk of HIV, and together sexual or drug risk in the past year was reported by 9.9 percent of persons 15-44 years of age. In total, 11.9 percent were estimated to be at increased risk for HIV by having reported sexual or drug-related risk behavior or having reported treatment for a sexually transmitted disease (STD) in the past year. This results in an estimate of 14.4 million persons at increased risk of HIV in the age group 15-44 (Table A).

- Males reported higher proportions at risk than females. For example, 13.0 percent of males $15-44$ were estimated to be at risk through reported sexual behavior or drug use or having been treated for an STD compared with 10.8 percent of females (Figure 1).

- The overall measure of risk through behavior or STD was higher for certain sociodemographic categories than others: non-Hispanic African-
Table A. Estimated percentage and estimated number (in thousands) of persons 15-44 years of age at increased risk of HIV, with standard errors by type of risk: United States, 2002

\begin{tabular}{|c|c|c|c|c|}
\hline Type of HIV risk & Percent & $\begin{array}{l}\text { Standard } \\
\text { error }\end{array}$ & $\begin{array}{l}\text { Number in } \\
\text { thousands }\end{array}$ & $\begin{array}{l}\text { Standard } \\
\text { error }\end{array}$ \\
\hline Risk from sexual behavior & 8.9 & 0.420 & 10,734 & 653 \\
\hline Risk from drug use. . . . . . . . . . . . . . . . & 1.5 & 0.167 & 1,843 & 205 \\
\hline Risk from sexual behavior or drug use $\ldots \ldots \ldots \ldots$ & 9.9 & 0.458 & 12,015 & 699 \\
\hline $\begin{array}{l}\text { Risk from sexual behavior, or drug use, or indicated by STD } \\
\text { treatment. } \ldots \ldots \ldots \ldots \ldots \ldots \ldots \ldots \ldots \ldots\end{array}$ & 11.9 & 0.476 & 14,358 & 745 \\
\hline
\end{tabular}

NOTE: HIV is human immunodeficiency syndrome and STD is sexually transmitted disease. SOURCE: National Survey of Family Growth Cycle 6 (2002).
Americans (20.4 percent) were more likely to be at risk than non-Hispanic white persons ( 9.7 percent); persons without a high school diploma or GED (15.8 percent) compared with college graduates (8.4 percent), those below 150 percent of the poverty level (16.7 percent) compared with persons at 400 percent of the poverty level or higher (10.0 percent), and those in the central cities of the 12 largest metropolitan areas (15.8 percent) compared with rural residents (9.1 percent) (Table 3 ).

- Drug-related risk was strongly related to sexual risk behavior: Among those who injected drugs or used crack cocaine, 31.3 percent reported sexual risk behavior compared with 8.5 percent of others (Table B).

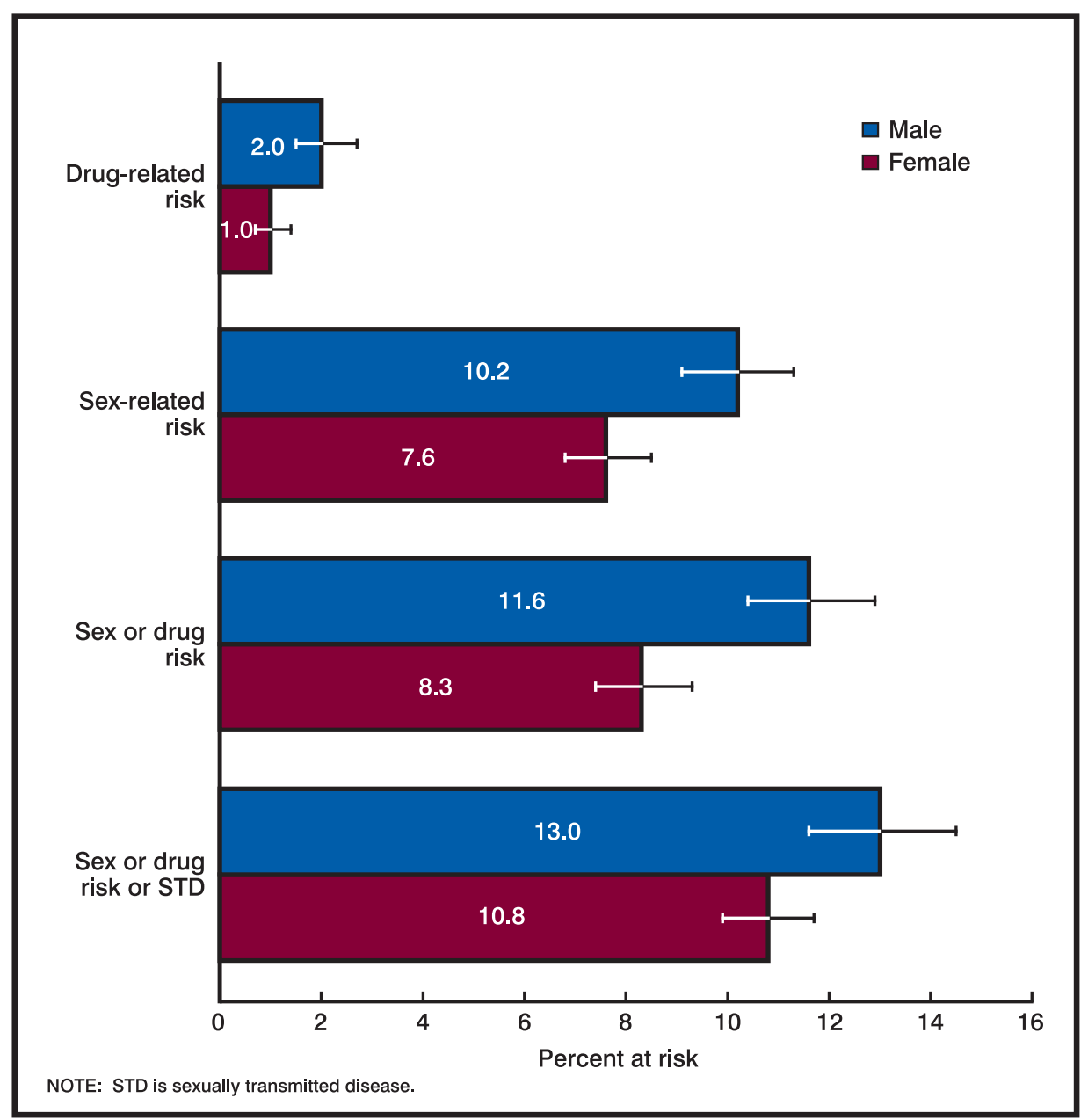

Figure 1. Percent of persons 15-44 years of age at risk for HIV through sex and drugrelated behavior, and 95 percent confidence intervals, by sex: United States, 2002 
Table B. Percentage of males and females 15-44 years of age who report sexual risk behaviors in the past year and the (standard error of the percent), by whether they used crack or injected drugs in the past year and type of sexual risk behavior: United States, 2002

\begin{tabular}{|c|c|c|c|}
\hline Type of sexual risk behavior & Total & $\begin{array}{l}\text { Used crack or } \\
\text { injected drugs }\end{array}$ & All others \\
\hline \multicolumn{4}{|l|}{ Male and female } \\
\hline Numbers in thousands. & 122,335 & 1,843 & 120,491 \\
\hline A. 5 or more sex partners $\ldots \ldots \ldots \ldots \ldots \ldots \ldots$ & $3.5(0.254)$ & *14.3 (3.767) & $3.3(0.239)$ \\
\hline$\ldots \ldots \ldots \ldots \ldots \ldots \ldots \ldots$ & $2.6(0.191)$ & *12.4 (3.087) & $2.5(0.175)$ \\
\hline C. Sex in exchange for money and/or drugs $\ldots \ldots \ldots \ldots \ldots \ldots$ & $2.3(0.181)$ & *16.2 (2.504) & $2.1(0.174)$ \\
\hline D. Sex with HIV+ partner $\ldots \ldots \ldots \ldots \ldots \ldots \ldots \ldots \ldots \ldots$ & $0.5(0.091)$ & $0.7(0.47)$ & $0.5(0.092)$ \\
\hline E. Any sex risk in past year $\ldots \ldots \ldots \ldots \ldots \ldots \ldots$ & $8.9(0.420)$ & *31.3 (4.456) & $8.5(0.408)$ \\
\hline \multicolumn{4}{|l|}{ Male only } \\
\hline Numbers in thousands & 61,147 & 1,233 & 59,694 \\
\hline F. Male-to-male sex... & $2.7(0.325)$ & $9.9(4.622)$ & $2.6(0.308)$ \\
\hline \multicolumn{4}{|l|}{ Female only } \\
\hline Numbers in thousands $\ldots \ldots \ldots \ldots \ldots \ldots \ldots \ldots \ldots \ldots \ldots$ & 61,561 & 610 & 60,798 \\
\hline G. Sex with man who has sex with men $\ldots \ldots \ldots \ldots \ldots$ & $2.3(0.221)$ & $5.4(3.392)$ & $2.3(0.212)$ \\
\hline
\end{tabular}

* The difference between drug users and others is significant at .05 or better using a weighted Chi-square test.

NOTE: IDU is Injecting drug user.

SOURCE: National Survey of Family Growth Cycle 6 (2002).

Table C. Estimated percentage and number of persons 15-44 years of age who have never been tested for HIV outside of blood donation, by whether at risk for HIV: United States, 2002

\begin{tabular}{|c|c|c|c|c|}
\hline \multirow[b]{2}{*}{ Risk status } & \multicolumn{4}{|c|}{ Never tested for HIV outside of blood donation } \\
\hline & Percent & $\begin{array}{l}\text { Standard } \\
\text { error }\end{array}$ & $\begin{array}{l}\text { Number in } \\
\text { thousands }\end{array}$ & $\begin{array}{l}\text { Standard } \\
\text { error }\end{array}$ \\
\hline Total $15-44$ years of age $\ldots \ldots \ldots \ldots \ldots$ & 49.3 & 0.806 & 59,917 & 1,973 \\
\hline At risk from sexual behavior, or drug use, or STD treatment . . . . . . & 33.6 & 1.677 & 4,797 & 347 \\
\hline All others & 51.2 & 0.819 & 54,168 & 1,711 \\
\hline
\end{tabular}

NOTE: HIV is human immunodefieincy syndrome and STD is sexually transmitted disease.

- Condom use during last sex was higher among those at risk (39.6 percent) compared with those not at risk (25.6 percent), but condoms were used by a minority of at-risk persons (Table 7).

- HIV testing was reported to a greater degree by persons at risk, but 33.6 percent of those who reported past year sexual or drug-related risk behaviors that put them at increased risk for HIV, or who had been treated for an STD, reported that they had never been tested for HIV (Table C). This is equivalent to 4.8 million at-risk untested persons aged 15-44.

\section{Introduction}

Prevention of HIV infection is a national health priority, and it has been recognized that accurate populationbased measurement of behaviors that put persons at risk for acquiring or transmitting HIV is an essential part of tracking the epidemic and developing successful prevention efforts (3). The use of national surveys to produce estimates of the prevalence of behaviors linked to HIV transmission has a relatively long history $(1,2,4-10)$, but there are few ongoing, large-scale surveys collecting data on a range of specific drug and sex-related behaviors. The National Survey of Family Growth has a number of advantages for producing estimates of this type. It has a long record of collecting sensitive reproductive-related information. In comparison to other national health surveys, it collects considerably more detailed information on risk behaviors related to HIV, it includes both drug and sexual behaviors related to HIV risk, and it uses data collection methods that enhance the degree of privacy for respondents in answering questions on these sensitive topics.

The objectives of this report are to use the data collected in the NSFG Cycle 6 to:

- Determine the number and percentage of individuals age 15-44 years who are at increased risk for HIV because of various sexual and drug-related behaviors that were reported on the survey

- Determine the demographic and other characteristics that are associated with HIV risk

- Determine the prevalence of preventive behaviors (HIV testing and condom use) for these populations

- Compare estimates of the size of HIV risk categories with estimates from other national surveys 


\section{Methods}

\section{Measuring HIV risk}

The risk categories used in this report are based on known HIV transmission routes and epidemiologic studies. The behaviors used here to define increased risk are based on the HIV/AIDS Reporting System (HARS), which defines a route of transmission for each case of HIV and AIDS (11). HARS defines transmission in terms of broad categories (male-to-male sexual contact, injection drug use, heterosexual contact) and not specific acts; the HARS procedure has been followed in this report. This method of defining persons at increased risk for HIV has been used in previous analytic studies that make use of self-reported survey data $(1,2)$.

In 2003, 45 percent of new cases of HIV and AIDS reported to CDC were to men who had sex with men (MSM), 19 percent to injecting drug users, and 34 percent were accounted for by heterosexual contact. Based on this, injecting drug use and male-to-male sex in the previous year have been used to define respondents as being at increased HIV risk. Regarding drug use, users of crack cocaine have also been classified as being at increased risk. Unlike drug injection, crack use does not provide a direct route for HIV transmission but it is widely considered an HIV risk factor because of its strong association with high-risk sexual behavior and other drug use and its consistent linkage to HIV infection in epidemiologic studies (12-21). Persons with five or more heterosexual sex partners in the past year were defined as at increased risk because of findings that larger numbers of sex partners tend to be associated with greater risk for sexually transmitted infections (22-25). Also considered to be at risk are persons who had any high-risk sex partner in the past year; this includes women who had male sex partners who had sex with other men, persons having sex with an injecting drug user (IDU), persons having an HIV-positive sex partner, and those who exchanged sex for drugs or money during the past year $(26,27)$. A final category of risk is reporting past year treatment for an STD.
To summarize, the following categories of past year HIV risk behavior have been defined:

- Risk related to sexual behavior in the past year:

1. Five or more opposite sex partners

2. Men having sex with other men

3. Sex with an injecting drug user (IDU)

4. Sex with an HIV-infected person

5. Exchange of sex for money or drugs

6. For females, sex with a man who has sex with other men

- Risk related to drug use in the past year:

1. Illicit drug injection

2. Crack cocaine use

- In addition, composite categories were defined based on the above behaviors in the past year:

1. Any risk related to sexual behavior (sexual behavior risk)

2. Any risk related to drug use (drug use risk)

3. Any risk from sexual behavior or drug use

4. Any risk related to sexual behavior or drug use or as indicated by treatment for an STD in the past year

The specific wording of the questions used to define these items is shown in the "Technical Notes."

In addition to drug- and sex-related HIV risk behaviors, measures of HIV preventive behavior have been defined. HIV testing is an important part of HIV prevention strategies, which seek to identify infected persons in order to provide appropriate treatment and prevention services (28). A measure of HIV testing was defined that includes the percentage who had ever received an HIV test other than those conducted automatically as part of blood donation (29). Condom use, for those who had been sexually active in the year before interview, was measured as the percentage reporting use during the last time they had had vaginal intercourse or (for males only) during the last episode of male-to-male oral or anal sex for males who reported that behavior. Males who reported sex with both females and males were categorized as condom users if they reported use during their most recent sex with either a male or a female.

\section{Data}

NSFG has been conducted six times by NCHS: in 1973, 1976, 1982, 1988, 1995, and 2002. The NSFG conducted in 2002, the sixth in the series, is referred to as Cycle 6. In 1973-95, the interviews were done with national samples of women 15-44 years of age. In Cycle 6, the national sample included both women and men 15-44 years of age.

Each time, the interviews have been conducted in person by trained female interviewers in the selected persons' homes. In Cycle 6, the sample was a nationally representative multistage area probability sample drawn from 121 areas across the United States. Large areas (counties and cities) were chosen first; within each large area or "primary sampling unit," groups of adjacent blocks, called segments, were chosen at random. Within segments, addresses were listed and some addresses were selected at random. The selected addresses were visited in person, and a short "screener" interview was conducted to see if anyone 15-44 years of age lived there. If so, one person was chosen at random for the interview and was offered a chance to participate. To protect the respondent's privacy, only one person was interviewed in each selected household. In Cycle 6, teenagers and black and Hispanic adults were sampled at higher rates than others.

All respondents were given written and oral information about the survey and were informed that participation was voluntary. Adult respondents 18-44 years of age were asked to sign a consent form but were not required to do so. For minors 15-17 years of age, signed consent was required first from a parent or guardian, and then signed assent was required from the minor. Respondents were guaranteed that the confidentiality of their information would be protected. The response rate for the survey was 79 percent -80 percent for women and 78 percent for men. 
Over 200 female interviewers were hired and trained by the survey contractor, the University of Michigan's Institute for Social Research, under the supervision of NCHS. Interviewing occurred between March 2002 and February 2003. Some of the data in this report were collected by CAPI, administered by an interviewer. The most sensitive items, on which estimates of HIV risk are based, were collected using ACASI, in which the respondent listened to the questions on headphones (or read them on the computer screen) and entered the responses directly into the computer, with no involvement of the interviewer. Respondents in the Cycle 6 survey were offered $\$ 40$ as a "token of appreciation" for their participation. The NSFG questionnaires and materials were reviewed by the CDC/NCHS Research Ethics Review Board and the University of Michigan Institutional Review Board. The female questionnaire lasted an average of 85 minutes, and the male questionnaire an average of 60 minutes. More detailed information about the methods and procedures of the study has been published elsewhere (30).

\section{Strengths and limitations of the data}

The data in this report are primarily from Cycle 6 of the NSFG, which has a number of strengths for studying sexual behavior in the U.S. population:

- The NSFG has a rigorous probability sampling design, which allows the estimates to be generalized to the national household population.

- The response rate for the NSFG was 79 percent, which is considered high, and suggests that the data for most statistics can be generalized to the household population with confidence.

- Questions asked on the NSFG have undergone intensive testing and review in an effort to make them understandable to persons participating in the survey.

- Sensitive questions on sexual behavior, reproductive health, or substance use were collected using ACASI methods, which have been found to yield more complete reporting of sensitive behaviors, and to avoid the large amounts of missing data often found on paper-and-pencil self-administered questionnaires (31,32).

- The questionnaire was administered in both English and Spanish; those who preferred to answer the interview in Spanish were interviewed by bilingual interviewers. The translation of the questionnaire into Spanish was done with particular attention to making it understandable and culturally appropriate to major Hispanic groups-including Mexicans, Puerto Ricans, recent immigrants, and those with limited education (30,33). The ACASI section of the interview was administered in Spanish or English according to the preference of the respondent, regardless of the language of the main interview.

The data included in this report also have a number of limitations:

- As a household-based sample survey, the NSFG excludes from the sampling frame the homeless, persons who are incarcerated or otherwise institutionalized, and those living on military bases in the United States. The results cannot be generalized to those populations; they may have different patterns of sexual and drug use behavior.

- As in any survey, nonresponse error could affect the results. The NSFG makes use of extensive quality control procedures to try to minimize the effects of such errors.

- The results could be affected by underreporting of sensitive behaviors, although using ACASI, as used in the NSFG, has been found to yield more complete reporting of these items than other types of questionnaires $(31,32)$.

- The NSFG provides national estimates but cannot provide state or local estimates of the behaviors described in this report.

- The age range of the NSFG is 15-44 years of age. Therefore, it is not possible to measure the behavior of those under age 15 or over 44 years of age, even though HIV risk behavior exists outside of this age range.

- Given the sample size of the Cycle 6 NSFG, the numbers of men and women in the sample who reported specific risk behaviors, although larger than in most other general population surveys, are still relatively small, resulting in larger sampling errors for these groups. It also means that the amount of subgroup analysis (for example, by age, race and ethnicity, and other characteristics) that can done for these populations is limited.

\section{Statistical analysis}

In the tables included in this report, the percentage and estimated number of persons in HIV risk categories have been computed for the total target population and for major population subgroups defined by sociodemographic categories. The percentage reporting HIV testing and condom use by categories of HIV risk have also been estimated. Each percentage estimate is shown with its standard error. Standard errors can be converted to confidence intervals by following procedures outlined in the "Technical Notes."

The statistical significance of bivariate associations has been evaluated using global Chi-square tests, testing the null hypothesis that the percentages in all the categories of a variable are equal. A significant test indicates that the categories being compared are not all equal, at the 0.05 level, and therefore, there is significant variation by that variable. Whereas the global Chi-square has been used throughout the report, in the text when two subgroups are contrasted, the statistical significance between the two subgroups has been assessed.

All estimates are based on weighting factors designed to produce unbiased estimates for the U.S. population. SUDAAN, release 9, software was used to adjust estimates and statistical tests for the complex sample design (34).

\section{Comparative survey data}

NSFG data on HIV risk were compared with data from four other national surveys. NSFG estimates of 
drug use behavior were compared with data on illegal drug injection and crack cocaine use from the National Survey on Drug Use and Health (NSDUH). NSDUH (formerly titled National Household Survey on Drug Abuse) is an annual national household-based survey conducted in all states that measures the prevalence and correlates of drug use in the United States among persons 12 years and over. Similar to the NSFG, the 2002 NSDUH was conducted using face-to-face interviews with computerassisted interviewing techniques, and the most sensitive drug use items (including those included in this report) were collected using ACASI methods. The total sample size of the 2002 NSDUH was 54,079 (of whom 37,247 were 18-44 years of age), and the overall response rate was estimated to be 79 percent (35).

Estimates of the number of opposite sex partners and reported male-to-male sex in the past year are compared with estimates from the General Social Survey (GSS). GSS, a national household-based probability sample of U.S. adults aged 18 and over, is designed to collect information on a variety of topics of social importance. GSS began asking questions on HIV-related behavior in 1988 as part of a special self-administered, paper-andpencil section of the interview completed by respondents following the main interviewer-administered interview (36). In recent years, GSS has been conducted in alternating years with samples of about 2,500 respondents. The overall response rates for recent GSS surveys have averaged around 70 percent. The percentages computed from the GSS that are presented here exclude those respondents who did not complete the self-administered questionnaire.

The National Health Interview Survey (NHIS) provides an estimate of the extent of self-reported STD treatment and also an indirect overall measure of the percentage of adults at increased HIV risk, with which to compare the NSFG estimates. (In the indirect measure of HIV risk, respondents are shown a list of HIV risk categories and are asked if any of these apply to them, without stating which one; wording is shown in the "Technical Notes.") NHIS is conducted annually and had a 2002 sample of 31,044 adults aged 18 and over, including 15,722 adults 18-44 years of age. It covers a range of general health topics using in-person, face-to-face household interviews, uses a household-based nationally representative sample, and has gathered data about HIV testing since 1987. In 2002, the overall response rate was 74.3 percent (37).

The Behavioral Risk Factor Surveillance System (BRFSS) also furnishes an indirect measure of overall HIV risk similar to the method used by the NHIS described previously (see "Technical Notes"), which can be compared with the NSFG estimates. BRFSS is a series of state surveys conducted annually in all states, uses telephone sampling, and conducts telephone interviews on a variety of health topics (38). The individual state response rates ranged from 42.2 to 82.6 percent (39). In 2002, a total of 188,952 adults aged $18-64$ in all states were asked questions about HIV risk.

\section{Results}

\section{Risk behaviors}

Table 1 shows the percentages of the population 15-44 years of age who reported each of the detailed risk behaviors for HIV. The following percentages reported behaviors in the past year that put them at risk of HIV: 3.0 percent had STD treatment in the past year; 3.5 percent reported five or more sexual partners; 2.6 percent had a sexual partner who injected illicit drugs; 2.3 percent had sex in exchange for money or drugs; and 0.5 percent reported sex with an HIV-infected person (Table 1). Among males, 2.7 percent reported sex with another male in the past year and 2.3 percent of females reported sex with a man who had sex with other men. Summary measures of risk from sexual behavior ("sex risk") and risk from drug use or sexual behavior ("sex or drug risk") were higher for males (Figure 1). For example, 13.0 percent of males reported any sex or drug risk or had been treated for an STD in the past year compared with 10.8 percent of females.

The summary risk measures in Table 1 indicate that overall 8.9 percent of persons 15-44 years old reported sexual behavior that increases their risk of HIV and 1.5 percent reported drug use that increases their risk of HIV; 9.9 percent reported either drug or sex behaviors that increased their risk. In the largest risk category, 11.9 percent reported either drug or sex risk or had been treated for an STD in the past year. The estimated number of persons at increased risk was 14.4 million persons aged 15-44, through drug use, sexual behavior, or having been treated for an STD in the past year (Table 1); a 95 percent confidence interval for this value would be approximately 13-16 million persons.

As Figure 2 indicates, overall measures of HIV risk vary greatly by race and ethnic group. Among Hispanics, 14.8 percent reported HIV risk behavior or STD treatment in the past year. The percentage at behavioral risk of HIV among non-Hispanic white persons was 9.7 percent and among non-Hispanic black persons,

20.4 percent. This is consistent with findings that Hispanic and non-Hispanic black persons have higher rates of HIV and AIDS cases in disease surveillance data (11).

To clarify the specific risk behaviors that account for these differences by Hispanic origin and race, these behaviors are shown for each of these groups in Table 2. The percentage at risk of HIV because of sexual behavior was higher for non-Hispanic black persons than for non-Hispanic white persons, in part, because of differences in the proportions who reported having five or more sex partners in the past year and in the proportions who had sex in exchange for money or drugs (Table 2). The percentage among both sexes who reported five or more previous year sex partners was 4.4 percent among Hispanic persons, 2.6 percent among non-Hispanic white persons, and 7.6 percent among non-Hispanic black persons. Reported levels of male-to-male sex were not significantly different among the three major race and 


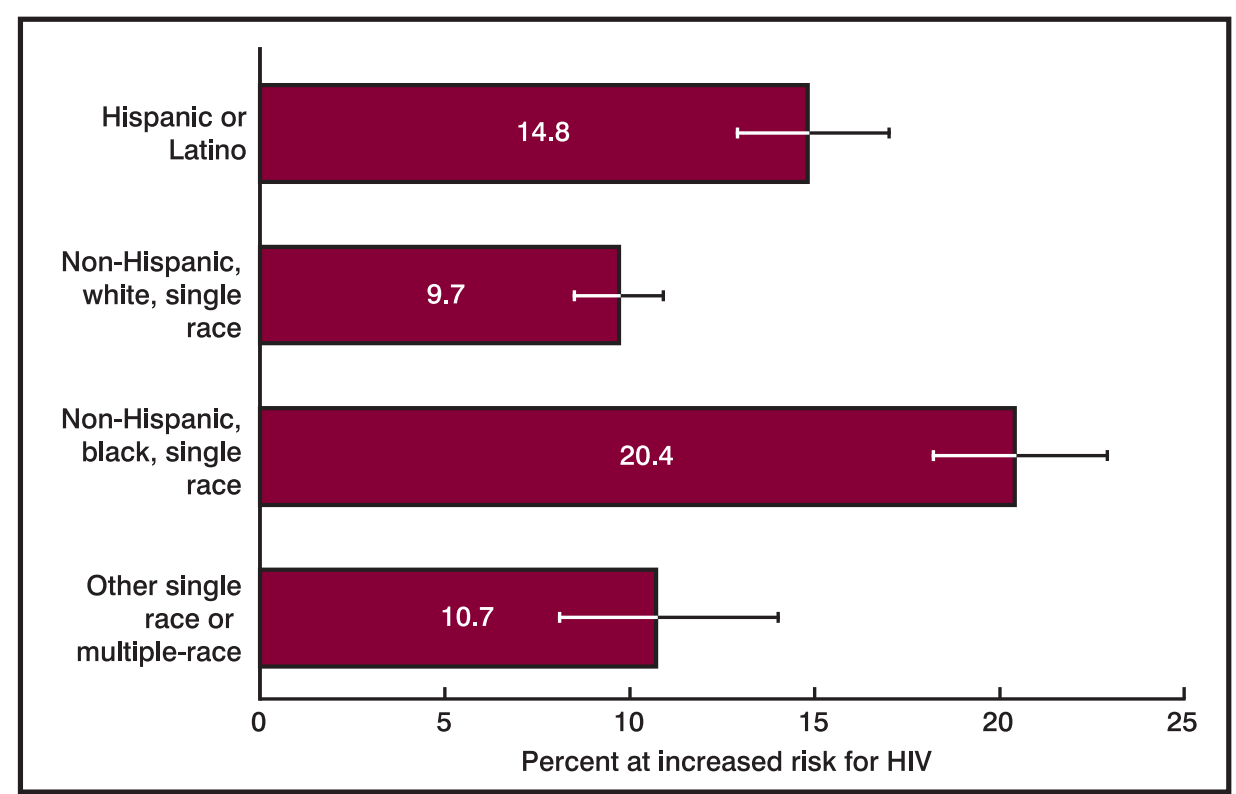

Figure 2. Percent of persons 15-44 years of age at increased risk for HIV and 95 percent confidence intervals, by Hispanic origin and race: United States, 2002 ethnicity categories, nor were measures of drug risk.

As Table 3 shows, measures of HIV risk behavior in the past year are not evenly distributed among major sociodemographic subgroups. Most differences among categories of the measures of sex and drug risk behaviors are statistically significant. Large differences in this measure of risk can be observed for a number of contrasting groups. For example, 16.5 percent of persons 20-24 years of age were at risk compared with 10.7 percent of those over age 30. Among those with less than a high school education, 15.8 percent were at risk compared with 8.4 percent of college graduates. Among those who were below 150 percent of the poverty level, 16.7 percent were at risk compared with 10.0 percent of those at 400 percent of the poverty level or greater. The data in Figure 3 also show that there was a strong association between risk behavior and residence. the 12 largest metropolitan areas, 15.8 percent were at risk compared with 9.1 percent of those in rural, nonmetropolitan areas. Finally, among males 25-44 years of age, 18.1 percent of those who had ever been incarcerated were at risk of HIV compared with 9.5 percent of those who had not been incarcerated. Among residents of the central cities of observable within gender categories, with risk higher at younger ages, among African Americans, in the lowest income categories, and in the central cities of metropolitan areas.

Table 5 shows differences in overall risk separately for the major race and ethnic groups. The percentage at risk is significantly higher for younger persons (15-24 years of age compared with 2544 years of age) and for those in central cities of metropolitan areas-but only among non-Hispanic white persons, not among non-Hispanic black persons. A different pattern is apparent for nonHispanic black persons, among whom statistically significant differences in risk are not observed by age or metropolitan residence. But black persons who had a bachelor's degree or higher, for example, had 13.5 percent in the at-risk category compared with 29.5 percent for those without a high school diploma or GED. Differences by education were not observed for Hispanic or non-Hispanic white persons. males and females. Males generally reported higher levels of risk but the same patterns of differences are

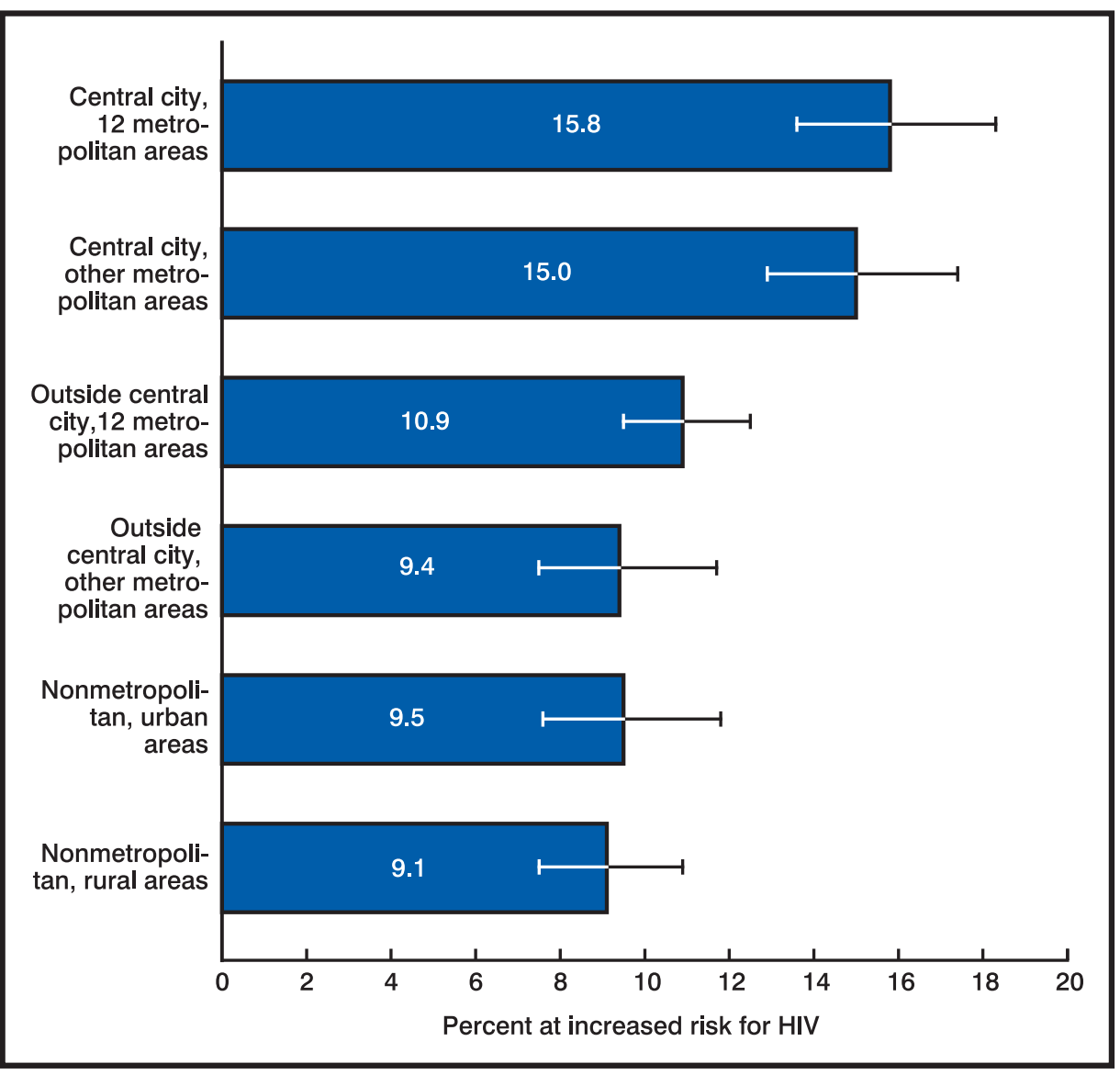

Figure 3. Percent of persons 15-44 years of age at increased risk for HIV and 95 percent confidence intervals, by metropolitan residence: United States, 2002 
NSFG provides a good opportunity to illustrate the strong association between sex and drug-related risk behaviors. Table B contains the percentage reporting sexual risk behaviors among those who reported drug injection or crack cocaine use in the past year, and generally shows considerably higher sexual risk behaviors among drug users compared with others. HIV risk from sexual behavior ("any sex risk"), for example, was reported by 31.3 percent of crack users and injectors compared with 8.5 percent of others. In the case of Table B, some cell sizes are quite small so that some apparent large differences are not statistically significant.

\section{HIV testing by HIV risk}

The NSFG can provide information about the HIV testing experience of persons at increased behavioral risk for acquiring HIV. HIV prevention strategies emphasize testing to identify infected persons and ensure access to appropriate medical care, treatment, and prevention services (28). It has been estimated that 1.0-1.2 million HIVinfected persons are living in the United States (40). As many as one in four of these may be unaware of their infection status (28). In addition, many HIVinfected persons become aware of their status late in their infection $(3,40)$. Information about the number and characteristics of at-risk persons who have never been tested is therefore important for prevention programs.

NSFG data indicate that overall about one-half of persons 15-44 years of age reported that they had never been tested for HIV outside of blood donation (Table 6). Females were less likely than males to report having never been tested: 45.1 percent of females compared with 53.4 percent of males. This reflects the recommendation that all women be tested during pregnancy and the fact that one-third of HIV tests among women are obtained for reasons of pregnancy (29). In general, persons at increased risk for HIV through specific drug or sex behaviors were less likely to report having never been tested. For example, 33.6 percent of those who reported sex or drug risk behavior or who had been treated for an STD in the past year reported that they had never had an HIV test outside of blood donation compared with 51.2 percent of others. As indicated in Table C, the 33.6 percent never tested in the high-risk group is equivalent to 4.8 million people who were at risk of HIV and had never been tested.

\section{HIV risk and condom use}

Promotion of condom use by persons at risk of acquiring or transmitting HIV or other sexually transmitted diseases to their sexual partners has been an important part of HIV prevention strategies (41). As shown in Table 7, 27.7 percent of persons 15-44 years of age reported using condoms the last time they engaged in vaginal or (for males) oral or anal sex. The NSFG data indicate that measures of sex risk and overall risk were strongly associated with condom use but measures of drug risk behavior were not. Among persons who reported any drug risk behavior as defined here, 23.4 percent reported using condoms during last sexual encounter compared with 27.7 percent of others, a difference that was not statistically significant. In contrast, 43.2 percent of persons with any sexual risk behavior reported condom use at last sex compared with 25.6 percent for others, a large and significant difference.

\section{Comparisons with other surveys: Reported drug use}

The components of drug risk included here-past year illegal injection and crack cocaine use - can be compared for the age group 15-44 with data from the 2002 National Survey on Drug Use and Health (NSDUH). Generally, the NSFG and NSDUH both report that overall reported use of crack is more common than injection, and that males are more likely to use crack than females (Table 8). The percentage reporting drug injection in the past year is low for both surveys, 0.4 percent in the NSFG and 0.2 percent in the NSDUH, and the difference between surveys is statistically significant. However, the questions used are different (see "Technical Notes"), and for NSDUH, illegal drug injection is limited to "cocaine, heroin, or stimulants," whereas the NSFG asks about any "nonprescription" drug injection, so the percentage reported might be expected to be somewhat higher. Both surveys indicate higher injection and crack use among males, but neither survey found statistically significant differences in the measures of drug use by Hispanic origin or race.

\section{Comparisons with other surveys: Risk from sexual behaviors}

Comparisons with data from the combined 2000-02 General Social Survey (GSS) indicate similar patterns for the percentage reporting two or more heterosexual sex partners in the past year. Table 9 shows that in both surveys, a higher percentage of males than females were at risk. The percentage reporting two or more partners was significantly higher in the GSS (19.3 percent) than in the NSFG (16.6 percent). The percentage reporting five or more partners- 3.6 percent in the NSFG and 3.1 percent in the GSSwas not significantly different in the two surveys. A greater percentage of females 18-44 years of age in the NSFG (2.4 percent) reported five or more partners in the past year than in the GSS ( 0.7 percent). Among males in the NSFG, 2.8 percent reported sex with a man in the past year compared with 4.5 percent in the GSS, a relatively large difference that was not statistically significant, probably related to the smaller sample size in the GSS.

\section{Comparisons with other surveys: Recent STD treatment}

The percentage reporting recent treatment for STDs can be compared with an estimate from the NHIS, which asked about treatment in the previous 5 years, not the past year as in NSFG. A small percentage reported treatment in both surveys. Despite using a 1-year time frame, the percentage is slightly higher in the NSFG-3.0 percent overall compared with 2.2 percent for NHIS for the last 5 years (Table 10). Given that NSFG asked about a shorter time interval and used ACASI data collection methods compared with the face-to-face interview conducted in NHIS, suggests 
that recent STD treatment may be more completely reported in the NSFG. NHIS found higher reporting of STD treatment among females compared with males, but in the NSFG, the percentages of males and females reporting STD treatment were similar.

\section{Summary risk measures for four surveys}

Measures that indicate some degree of increased risk for HIV infection are computed by a number of health surveys. These indicators of risk are of value for data analysis, in particular in examining behaviors related to prevention, such as HIV testing and condom use, but these measures vary widely from survey to survey in how they are measured and constructed. Because of these differences in the ways that the questions were asked, the estimates of the level of HIV risk from these four surveys are not strictly comparable, but there is some benefit in assessing the overall level of risk implied by the differing methodologies.

For two surveys, the NSFG and GSS, the measures of risk are based on individual questions on self-administered questionnaires, asking about recent drug and sex-related behavior. These are direct measures of risk. Two general health surveys, the NHIS and the BRFSS, do not ask about specific risk behaviors, but present respondents with a list of behaviors and ask if any apply to the respondent without asking the respondent to state which one. These may be considered an indirect measure of risk. The direct measure from the
NSFG results in an overall estimate of 10.2 percent of 18-44 year olds at risk; using the direct measure in the GSS, 7.2 percent were classified as being at increased risk (Table D). The surveys provide similar estimates of risk among males (11.9 and 12.7 percent) but differing levels among females (8.5 percent from the NSFG and 2.3 percent from the GSS).

The two indirect measures from the NHIS and BRFSS yield remarkably similar overall levels of increased risk, 4.9 and 5.1 percent, despite the fact that they are based on different lists of risk behaviors and time periods (Table D). The four surveys suggest that using varying methods of defining risk results in a range of estimates of between 510 percent of persons $18-44$ years of age in the United States being at increased risk for HIV.

\section{Discussion}

Using the methods described here, in 2002, an estimated 11.9 percent of persons aged 15-44 in the United States could be considered to be at some increased behavioral risk for acquiring or transmitting HIV infection, representing 14.4 million persons. The levels of risk estimated from the NSFG were of a similar order of magnitude but tended to be somewhat higher than the results of other national surveys, which using various methods estimated 57 percent at behavioral risk. Many of the component risk behaviors are highly sensitive and subject to underreporting in surveys. The ACASI methods employed by the NSFG have been found to be associated with higher (and presumably more complete) reporting of sensitive behaviors than other modes of interviewing $(31,32)$.

Although these NSFG estimates of HIV risk behaviors appear to be of good quality, they also may be affected by some degree of underreporting. For example, survey estimates of selfreported illegal drug injection are usually understood to be underestimates of the actual numbers injecting and methods using other data have been developed to adjust them $(42,43)$. One such adjusted estimate of the total number of persons in the United States who have injected drugs in the past year is 1.4 million (43), which can be compared with the NSFG estimate of $329,000-657,000$ past year injectors for the limited age range of 15-44.

Similarly, behaviors such as male-to-male sex in the last year also may be underreported to some degree. The NSFG estimate of 2.7 percent is similar to other large surveys that have generally found about 2-3 percent of men reporting this behavior in the last year $(5,7,8,45-47)$. One review of data has suggested that the percentage might be about $4-6$ percent-two times this level (47).

In addition to possible underreporting of sensitive behaviors, the NSFG results are subject to other limitations of a survey of the household population of the United States: most military personnel, the homeless, and persons who are incarcerated or otherwise institutionalized are excluded from the sample. It is possible that those populations have disproportionate

Table D. Estimated percentages of adults 18-44 years of age at increased risk for HIV, with standard errrors and number of sample cases in the survey in four National Surveys: United States

\begin{tabular}{|c|c|c|c|c|c|c|c|c|c|}
\hline \multirow[b]{2}{*}{ Surveys } & \multicolumn{3}{|c|}{ Total } & \multicolumn{3}{|c|}{ Male } & \multicolumn{3}{|c|}{ Female } \\
\hline & Percent & $\begin{array}{l}\text { Standard } \\
\text { error }\end{array}$ & $\begin{array}{l}\text { Sample } \\
\text { number }\end{array}$ & Percent & $\begin{array}{l}\text { Standard } \\
\text { error }\end{array}$ & $\begin{array}{l}\text { Sample } \\
\text { number }\end{array}$ & Percent & $\begin{array}{l}\text { Standard } \\
\text { error }\end{array}$ & $\begin{array}{l}\text { Sample } \\
\text { number }\end{array}$ \\
\hline \multicolumn{10}{|l|}{ Direct measures: } \\
\hline Cycle 6 National Survey of Family Growth (NSFG) . . & 10.2 & 0.505 & 11,070 & 11.9 & 0.713 & 4,199 & 8.5 & 0.516 & 6,871 \\
\hline 2000-02 General Social Survey (GSS) . . . . . . . . . . . . . . & 7.2 & 0.736 & 2,426 & 12.7 & 1.388 & 1,107 & 2.3 & 0.573 & 1,319 \\
\hline \multicolumn{10}{|l|}{ Indirect measures: } \\
\hline 2002 National Health Interview Survey (NHIS). & 4.9 & 0.179 & 15,722 & 5.8 & 0.332 & 7,042 & 4.1 & 0.255 & 8,680 \\
\hline 2002 Behavior Risk Factor Surveillance Survey (BRFSS) . . . . & 5.1 & 0.153 & 101,451 & 5.6 & 0.230 & 41,934 & 4.6 & 0.153 & 59,517 \\
\hline
\end{tabular}

Definitions:

NSFG males: In past year: drug injection or crack cocaine use, five or more sex partners, male-to-male sex, sex partner who is: injecting drug user (IDU), exchange partner, HIV+ partner. NSFG females: In past year: drug injection or crack cocaine use, five or more sex partners, sex partner who is: MSM, IDU, exchange partner, or HIV+ partner.

GSS: IDU or crack cocaine in past 3 years, in past year: five or more partners, male-to-male sex, sex in exchange for money.

NHIS: Any statement is true: have hemophilia, ever had male-to-male sex, ever injected drugs, ever exchanged sex for drugs and/or money, HIV positive; or have a high or medium chance of acquiring HIV.

BRFSS: Any statement is true: in past year IDU, treated for sexually transmiited disease (STD), sex in exchange for money and/or drugs, unprotected anal intercourse. 
percentages at increased risk for HIV. Nonresponse error also could affect the results, but the NSFG makes use of weighting factors to compensate for nonresponse and unequal selection probabilities.

The method of defining HIV risk used here is only one possible method for using the NSFG data, and other researchers could choose different approaches. The method presented in this report is based on route-oftransmission categories in CDC's HIV/AIDS reporting system (HARS), which emphasizes exposure to certain types of sex partners rather than types of sexual activity. The sexual information collected by the NSFG in the ACASI section are more detailed than those collected on other general population health surveys, but are limited in the ability to study sexual behavior in detail. The NSFG collects numbers of opposite-sex partners in the last year with whom respondents had vaginal, oral, or anal sex, but it is not possible, for example, to determine the number of partners with whom they had anal sex in the past year. The definitions used here are supported by previous epidemiologic studies, and the approach has been used in other analytic studies. Increased risk for HIV, as defined here, is strongly associated with HIV preventive behavior (HIV testing, condom use), as well as other factors known to be associated with HIV infection, including race and ethnicity, sex, and socioeconomic variables. The focus of this report is limited to sexual and drug use behaviors that are closely linked to HIV transmission. Other reports based on Cycle 6 of the NSFG present results on a wider range of sexual behaviors (48), as well as other descriptive statistics related to the individual risk behaviors analyzed here $(49,50)$.

The NSFG data reported here illustrate the value of collecting survey data on HIV risk together with data on HIV preventive behaviors such as HIV testing and condom use. HIV prevention strategies emphasize HIV testing because studies have shown that many infected persons are unaware of their infection status, or have become aware late in the infection $(40,51,52)$. The
Cycle 6 NSFG data indicate that one-third of persons who reported increased risk for HIV also report that they have never been tested for HIV, which is equivalent to about 4.8 million persons. Similarly, the survey data indicate that persons at increased risk were more likely to use condoms (particularly those at risk through sexual behavior), but that most at-risk persons (60.4 percent) did not use condoms during their most recent sexual encounter.

The importance of survey research assessments to the success of HIV prevention efforts has been recognized (3). Additional work is ongoing to evaluate and improve measurement techniques, to collect data needed to evaluate programs, and to identify those population groups most at risk. Nationally representative, populationbased surveys such as NSFG can play an essential role, in combination with local surveys and surveys of high- risk populations, in measuring the overall effectiveness of HIV prevention strategies.

\section{References}

1. Anderson JE, Wilson RW, Barker P, et al. Prevalence of sexual and drug-related HIV risk behaviors in the U.S. adult population: Results of the 1996 National Household Survey on Drug Abuse. JAIDS 21:148-56. 1999.

2. Anderson JE, Stall R. How many people are at risk for HIV in the United States? The need for behavioral surveys of at-risk populations. JAIDS 29:104-5. 2002.

3. Institute of Medicine. No time to lose: Getting more from HIV prevention. Washington, DC: National Academy Press. 2000.

4. Catania J, Coates T, Stall R, et al. Prevalence of AIDS-related risk factors and condom use in the United States. Science 258(13):1101-5. 1992.

5. Billy J, Tanfer K, Grady W, Klepinger D. The sexual behavior of men in the United States. Fam Plann Perspect 25:52-60. 1993.

6. Leigh B, Temple M, Trocki K. The sexual behavior of U.S. adults: Results of a national survey. AJPH 83:1400-7. 1993.
7. Laumann E, Gagnon J, Michael R, Michaels S. The Social Organization of Sexuality. Chicago: University of Chicago Press. 1994.

8. Turner C, Danella R, Rogers S. Sexual behavior in the United States, 1930-90. Sex Transm Dis 22:173-90. 1995.

9. Sonenstein F, Ku L, Lindberg L, Turner C, Pleck J. Changes in sexual behavior and condom use among teenaged males: 1988 to 1995 . AJPH 88:956-9. 1998.

10. Holtzman D, Bland SD, Lansky A, Mack KA. HIV-related behaviors and perceptions among adults in 25 states: 1997 Behavioral Risk Factor Surveillance System. AJPH 91:18828. 2001.

11. Centers for Disease Control and Prevention. HIV/AIDS Surveillance Report, 2003. 15:1-46. 2004.

12. Edlin BR, Irwin KL, Faruque S, et al. Intersecting epidemics-crack cocaine use and HIV infection among inner-city young adults. N Engl J Med 331:1422-7. 1994.

13. DeHovitz JA, Kelly P, Feldman J, et al. Sexually transmitted diseases, sexual behavior, and cocaine use in inner-city women. Am J Epidemiol 140:1125-34. 1994.

14. Ellerbrock TV, Harrington PE, Bush TJ, et al. Risk of human immunodeficiency virus infection among pregnant crack cocaine users in a rural community. Obstet Gynecol 86:400-4. 1995.

15. Irwin KL, Edlin BR, Faruque $S$, et al. Crack cocaine smokers who turn to drug injection: Characteristics, factors associated with injection, and implications for HIV transmission. Drug \& Alcohol Dependence 42:85-92. 1996.

16. Word CO, Bowser B. Background to crack cocaine addiction and HIV high-risk behavior: The next epidemic. Am J Drug Alcohol Abuse 23:67-77. 1997.

17. Campsmith ML, Nakashima AK, Jones JL. Association between crack cocaine use and high-risk sexual behaviors after HIV diagnosis. JAIDS 25:192-8. 2000.

18. Wilson T, DeHovitz JA. STDs, HIV, and crack cocaine: A review. AIDS Patient Care STDs 11:62-6. 1997.

19. Logan TX, Leukefeld C, Farabee D. Sexual and drug use behaviors among women crack users: Implications for prevention. AIDS Educ Prev 10:327-40. 1998. 
20. McCoy HV, Wasserman A. Gender differences in condom usage among rural crack-using men and women. Women Health 33:143-62. 2001.

21. Fernando D, Schilling RF, Fontdevila J, El-Bassel N. Predictors of sharing drugs among injection drug users in the South Bronx: Implications for HIV transmission. J Psychoactive Drugs 35:227-36. 2003.

22. Stergachis A, Scholes D, Heidrich FE, et al. Selective screening for Chlamydia trachomatis infection in a primary care population of women. Am J Epidemiol 138:143-53. 1993.

23. Mosure DJ, Berman S, Fine D, et al. Genital Chlamydia infections in sexually active female adolescents: Do we really need to screen everyone? J Adol Health 20:6-13. 1997.

24. Rosenberg MD, Gurvey JE, Adler N, et al. Concurrent sex partners and risk for sexually transmitted diseases among adolescents. Sex Transm Dis 26:208-12. 1999.

25. Erbelding EJ, Chung SE, Kamb ML, et al. New sexually transmitted diseases in HIV-infected patients: Markers for ongoing HIV transmission behavior. JAIDS 33:247-52. 2003.

26. Astemborski J, Vlahov D, Warren D, et al. The trading of sex for drugs or money and HIV seropositivity among female intravenous drug users. AJPH 84:382-7. 1994.

27. Booth RE, Kwiatkowski CF, Chitwood DD. Sex related HIV risk behaviors: Differential risks among injection drug users, crack smokers, and injection drug users who smoke crack. Drug Alcohol Depend 58:21926. 2000.

28. Centers for Disease Control and Prevention. Advancing HIV Prevention: New Strategies for a Changing Epidemic: United States, 2003. MMWR 52:329-32. 2003.

29. Anderson JE, Chandra A, Mosher W. HIV testing in the United States, 2002. Advance data from vital and health statistics; no 363 . Hyattsville, MD: National Center for Health Statistics. 2005.

30. Groves RM, Benson G, Mosher WD, et al. Plan and operation of Cycle 6 of the National Survey of Family Growth. National Center for Health Statistics. Vital Health Stat 1(42). 2005.

31. Tourangeau R, Smith TW. Asking sensitive questions: The impact of data collection mode, question format, and question context. Public Opinion Quarterly 60:275-304. 1996.

32. Turner C, Ku L, Rogers S, Lindberg L, Pleck J, Sonenstein F. Adolescent sexual behavior, drug use, and violence: Increased reporting with computer survey technology. Science 280:867-73. 1998.

33. Martinez G, Marin B, and SchuaGlusberg A. Translating from English to Spanish: the 2002 National Survey of Family Growth. Hispanic J Behav Sci 28(4):1-15. 2006.

34. Research Triangle Institute. SUDAAN Language Manual, Release 9.0 Research Triangle Park, NC. 2004.

35. U.S. Department of Health and Human Services, Substance Abuse and Mental Health Services Administration, Office of Applied Studies. National Survey on Drug Use and Health, 2002 [Computer file]. Research Triangle Park, NC: Research Triangle Institute. 2004.

36. Davis JA, Smith TW. General Social Surveys, 1972-2002 cumulative codebook. National Opinion Research Center, Chicago. 2003.

37. Centers for Disease Control and Prevention. National Center for Health Statistics, 2002 National Health Interview Survey (NHIS) Public Use Data Release, NHIS Survey Description, Division of Health Interview Statistics, National Center for Health Statistics, Hyattsville, MD. 2003.

38. Centers for Disease Control and Prevention. 2002 BRFSS survey data public-use data and documentation, http://www.cdc.gov/brfss/ technical_infodata/surveydata/ 2002.htm., accessed April 2004.

39. Centers for Disease Control and Prevention, National Center for Chronic Disease Prevention and Health Promotion, 2002 Summary Behavioral Risk Factor Surveillance System, Summary Data Quality Report, Division of Adult and Community Health, NCCDPHP, Atlanta, GA. 2003.

40. Glynn M, et al. Estimated HIV prevalence in the United States at the end of 2003. 2005 National HIV Prevention Conference, June 12-15, 2005. Atlanta GA. Abstract 595.

41. Centers for Disease Control and Prevention, HIV Prevention Strategic Plan through 2005. Atlanta, Georgia. 2001.
42. Wright D, Gfroerer J, Epstein J. Ratio estimation of hardcore drug use. J Official Stat 13:401-6. 1997.

43. Friedman SR, Tempalski B, Cooper $\mathrm{H}$, Perlis T, et al. Estimating the numbers of injecting drug users in metropolitan areas for structural analyses of community vulnerability and for assessing relative degrees of service provision for injecting drug users. J Urban Health 81:377-400. 2004.

44. Fay RE, Turner CF, Klassen AD, et al. Prevalence and patterns of same-gender sexual contact among men. Science 243:338-48. 1989.

45. Michaels S. The prevalence of homosexuality in the United States, pp. 43-63. In: Cabaj R, Stein T, eds. Textbook of homosexuality and mental health. Washington, DC: American Psychiatric Press 43-63. 1996.

46. Anderson JE, Stall R. Increased reporting of male-to-male sexual activity in a national survey, Sex Transm Dis 29 11:643-6. 2002.

47. Diamond M. Homosexuality and bisexuality in different populations. Archives of sexual behavior 22:291310. 1993.

48. Mosher WD, Chandra A, Jones J. Sexual behavior and selected health measures: Men and women 15-44 years of age, United States, 2002. Advance data from vital and health statistics; no 362. Hyattsville, MD: National Center for Health Statistics. 2005.

49. Chandra A, Martinez GM, Mosher WD, Abma JC, Jones J. Fertility, family planning, and reproductive health of U.S. women: Data from the 2002 National Survey of Family Growth. National Center for Health Statistics. Vital Health Stat 23(25). 2005.

50. Martinez GM, Chandra, A, Abma JC, Jones J, Mosher WD. Fertility, contraception, and fatherhood: Data on men and women from the 2002 National Survey of Family Growth. National Center for Health Statistics. Vital Health Stat 23(26). 2006.

51. Centers for Disease Control and Prevention. Unrecognized HIV infection, risk behaviors, and perceptions of risk among young black men who have sex with menSix U.S. cities, 1994-98. MMWR 51:733-6. 2002.

52. MacKellar DA, Valleroy LA, Secura GM, et al. Unrecognized HIV 
infections, risk behaviors, and perceptions of risk among young men who have sex with men: Opportunities for advancing HIV prevention in the third decade of HIV/AIDS. JAIDS 38(5):603-14. 2005.

53. Kleinbaum DG, Kupper LL, Morgenstern H. Epidemiologic research: Principles and quantitative methods, San Jose, CA: Lifetime Publications 297-9. 1983.

54. U.S. Census Bureau. Statistical Abstract of the United States: 2003 (123rd Edition). Washington, DC. Tables 152, 227, 228, 684, 687, and 697. 2003.

55. Mosher WD, Deang LP, Bramlett MD. Community environment and women's health outcomes:

Contextual data. National Center for Health Statistics. Vital Health Stat 23(23). 2003.

56. Lepkowski JM, Mosher WD, Davis KE, et al. National Survey of Family Growth, Cycle 6: Sample design, weighting, imputation, and variance estimation. National Center for Health Statistics. Vital Health Stat 2(142). 2006. 
Table 1. Number of males and females 15-44 years of age and percentage at risk of HIV by type of risk, with the standard error of each percentage: United States, 2002

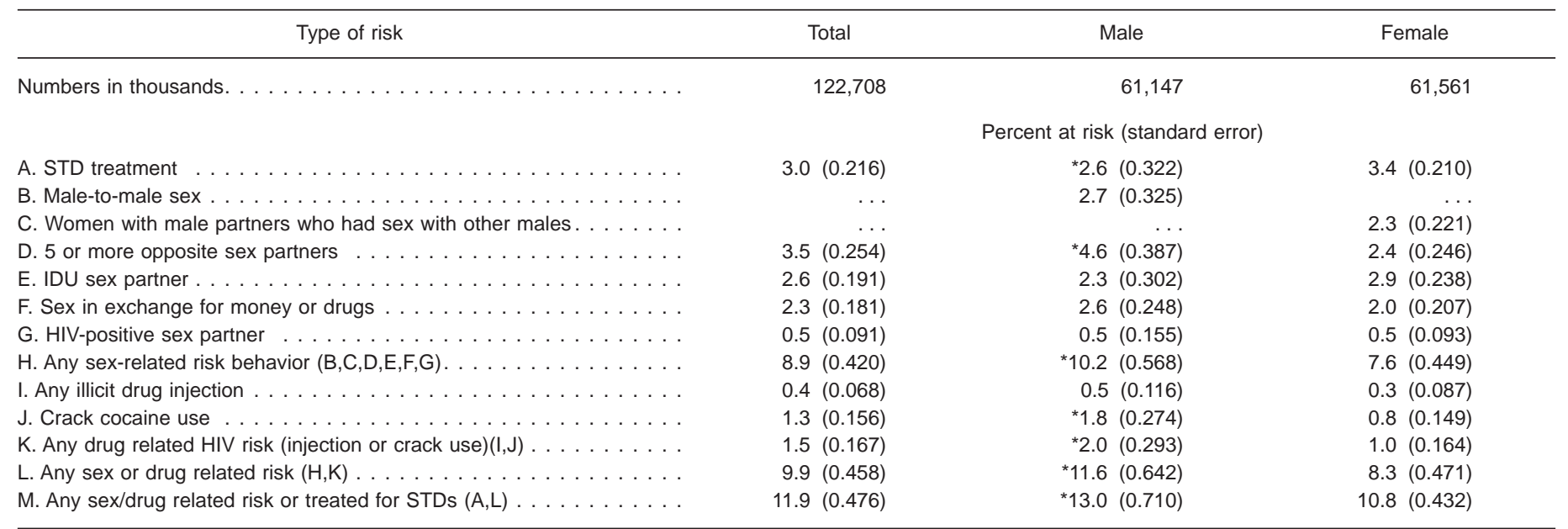

* Values for males and females are different; $p<.05$, Weighted Chi-Square statistically significant. ... Category not applicable.

NOTE: IDU is injecting drug user and STD is sexually transmitted disease.

SOURCE: National Survey of Family Growth Cycle 6 (2002). 
Table 2. Number of males and females 15-44 years of age by race and ethnic group, and percentage at risk of HIV by type of risk (with the standard error of each percentage): United States, 2002

\begin{tabular}{|c|}
\hline Type of risk \\
\hline Both sexes \\
\hline Numbers in thousands. . . . . . . . . . . . . . . . . . . \\
\hline 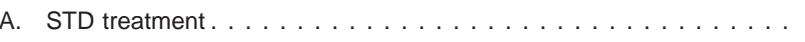 \\
\hline 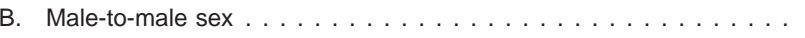 \\
\hline C. Female with MSM partner ${ }^{1} \ldots \ldots \ldots \ldots \ldots \ldots$ \\
\hline D. 5 or more opposite sex partners . . . . . . . . . . . . . . . \\
\hline 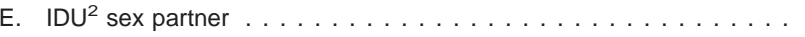 \\
\hline F. Sex in exchange for money or drugs $\ldots \ldots \ldots \ldots \ldots$ \\
\hline G. HIV positive sex partner . . . . . . . . . . . . . . . . . \\
\hline H. Any sex-related risk behavior $(\mathrm{B}, \mathrm{C}, \mathrm{D}, \mathrm{E}, \mathrm{F}, \mathrm{G}) \ldots \ldots \ldots \ldots$ \\
\hline 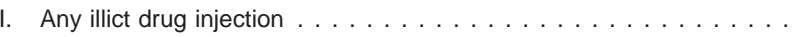 \\
\hline 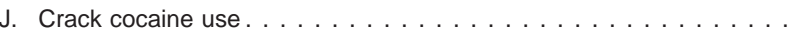 \\
\hline K. Any drug related HIV risk (injection or crack)(I and J) . . . . . . . . \\
\hline L. Any sex or drug related risk $(\mathrm{H}$ and $\mathrm{K}) \ldots \ldots \ldots \ldots \ldots$ \\
\hline M. Any sex or drug related risk, or STD treatment $(A$ and $L) \ldots \ldots \ldots$ \\
\hline
\end{tabular}

\section{Male}

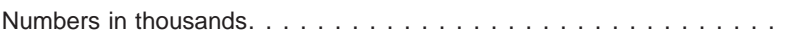

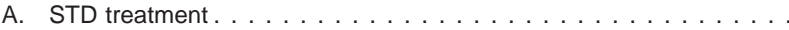

C. Female with MSM partner. . . . . . . . . . . . .

D. 5 or more opposite sex partners . . . . . . . . . . . . . .

E. IDU sex partner . . . . . . . . . . . . . . . . . .

F. Sex in exchange for money or drugs $\ldots \ldots \ldots \ldots \ldots \ldots$

G. HIV positive sex partner . . . . . . . . . . . . . . .

$\mathrm{H}$. Any sex-related risk behavior $(\mathrm{B}, \mathrm{D}, \mathrm{E}, \mathrm{F}, \mathrm{G}) \ldots \ldots \ldots \ldots$

I. Any illict drug injection . . . . . . . . . . . . . . .

J. Crack cocaine use. . . . . . . . . . . . . . . . . . .

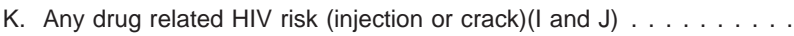

L. Any sex or drug related risk $(\mathrm{H}$ and $\mathrm{K}) \ldots \ldots \ldots \ldots$

M. Any sex or drug related risk, or STD treatment $(A$ and $L) \ldots \ldots \ldots$.

\section{Female}

Numbers in thousands. . . . . . . . . . . . . . . . .

A. STD treatment . . . . . . . . . . . . . . . . .

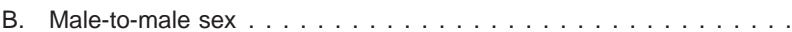

C. Female with MSM partner. . . . . . . . . . . . .

D. 5 or more opposite sex partners ...............

E. IDU sex partner . . . . . . . . . . . . . . . . .

F. Sex in exchange for money or drugs . . . . . . . . . . . . .

G. HIV positive sex partner . . . . . . . . . . . . .

H. Any sex-related risk behavior $(\mathrm{C}, \mathrm{D}, \mathrm{E}, \mathrm{F}, \mathrm{G}) \ldots \ldots \ldots \ldots$

I. Any illict drug injection . . . . . . . . . . . . .

J. Crack cocaine use . . . . . . . . . . . . . . . . . . .

K. Any drug related HIV risk (injection or crack)(I and $\mathrm{J}$ ) . . . . . . . .

L. Any sex or drug related risk $(\mathrm{H}$ and $\mathrm{K}) \ldots \ldots \ldots \ldots$

$M$. Any sex or drug related risk, or STD treatment $(A$ and $L) \ldots \ldots \ldots$.
B. Male-to-male sex . . . . . . . . . . . . . . . . .
19,295

*4.1 (0.598)

.

*4.4 (0.490)

*2.9(0.386)

*2.7 (0.363)

*0.8 (0.293)

*10.5 (0.721)

$0.5(0.143)$

$1.6(0.398)$

$1.9(0.434)$

*12.1 (0.826)

*14.8 (1.033)

10,188

*4.1 (0.862)

$2.9(0.466)$

*6.3 (0.926)

$3.4(0.592)$

*3.6(0.577)

$1.2(0.506)$

*13.4 (1.196)

$0.4(0.233)$

$2.3(0.679)$

$2.6(0.753)$

*15.6 (1.367)

*17.6 (1.591)

\section{9,107}

*4.1 (0.526)

*2.7 (0.41)

*2.2( $(0.343)$

*2.4 (0.399)

*1.6 (0.318)

${ }^{*} 0.4(0.168)$

*7.4 (0.657)

*0.6 (0.156)

$0.8(0.272)$

$1.1(0.278)$

*8.2(0.695)

*11.7 (0.833)

$\begin{array}{cc}\text { Non- } & \text { Non- } \\ \text { Hispanic } & \text { Hispanic } \\ \text { white } & \text { black }\end{array}$

78,237

15,190

Percent (standard error)

$2.2(0.262)$

$5.3(0.487)$

...

$2.6(0.328)$

$2.1(0.266)$

$1.7(0.228)$

$0.3(0.105)$

$7.2(0.537)$

$0.4(0.081)$

$1.0(0.183)$

$1.2(0.194)$

$8.1(0.598)$

$9.7(0.604)$

$4.7(0.402)$

$5.1(0.472)$

$0.8(0.183)$

$16.0(1.027)$

$0.6(0.266)$

$1.8(0.352)$

$2.1(0.363)$

$17.2(1.125)$

$20.4(1.202)$

$1.8(0.396)$

$2.7(0.421)$

6,940

$5.4(0.617)$

$3.0(0.721)$

$3.2(0.445)$

$1.8(0.407)$

$1.8(0.318)$

$0.3(0.183)$

$8.4(0.730)$

$0.5(0.143)$

$1.5(0.347)$

$1.7(0.376)$

$9.6(0.851)$

$10.7(0.926)$

10.9 (1.685)

$3.1(0.463)$

$5.9(0.733)$

$0.5(0.213)$

$17.4(1.525)$

$0.9(0.542)$

$3.0(0.675)$

$3.2(0.693)$

19.1 (1.600)

22.0 (1.729)

* Indicates that the differences in the percents between the categories of race and ethnicity are significant at the .05 level using a weighted Chi-Square test. ${ }^{1} \mathrm{MSM}$ is man who has sex with men.

${ }^{2}$ IDU is injecting drug user.

SOURCE: National Survey of Family Growth Cycle 6 (2002).
39,498

$2.7(0.265)$

$1.8(0.260)$

$2.0(0.327)$

$2.4(0.357)$

$1.6(0.261)$

$0.3(0.100)$

$6.0(0.543)$

$0.3(0.127)$

$0.5(0.134)$

$0.7(0.167)$

$6.5(0.555)$

$8.6(0.522)$
8,250

$5.3(0.667)$

$3.3(0.609)$

$4.8(0.819)$

$6.1(0.668)$

$4.4(0.679)$

$1.1(0.281)$

$14.9(1.220)$

$0.30 .168)$

$0.8(0.248)$

$1.1(0.269)$

$15.6(1.287)$

19.1 (1.344) 


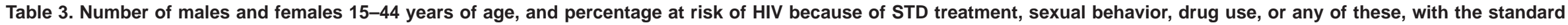
error of each percentage, by selected characteristics: United States, 2002

\begin{tabular}{|c|c|c|c|c|c|c|c|c|c|c|c|}
\hline \multirow[b]{2}{*}{ Characteristic } & \multirow{2}{*}{$\begin{array}{l}\text { Numbers } \\
\text { in } \\
\text { thousands }\end{array}$} & \multicolumn{2}{|c|}{ STD treatment in past year } & \multicolumn{2}{|c|}{$\begin{array}{l}\text { Risk from } \\
\text { sexual behavior }\end{array}$} & \multicolumn{2}{|c|}{ Risk from drug use } & \multicolumn{2}{|c|}{$\begin{array}{l}\text { Risk from sexual } \\
\text { behavior or drug use }\end{array}$} & \multicolumn{2}{|c|}{$\begin{array}{l}\text { Risk from sexual } \\
\text { behavior or drug } \\
\text { use or STD }\end{array}$} \\
\hline & & Percent & $\begin{array}{l}\text { Standard } \\
\text { error }\end{array}$ & Percent & $\begin{array}{l}\text { Standard } \\
\text { error }\end{array}$ & Percent & $\begin{array}{l}\text { Standard } \\
\text { error }\end{array}$ & Percent & $\begin{array}{l}\text { Standard } \\
\text { error }\end{array}$ & Percent & $\begin{array}{l}\text { Standard } \\
\text { error }\end{array}$ \\
\hline Total, both sexes. & 122,708 & 3.0 & 0.216 & 8.9 & 0.420 & 1.5 & 0.167 & 9.9 & 0.458 & 11.9 & 0.476 \\
\hline \multicolumn{12}{|l|}{ Sex } \\
\hline$\ldots$ & 61,147 & *2.6 & 0.322 & ${ }^{*} 10.2$ & 0.568 & ${ }^{*} 2.0$ & 0.293 & *11.6 & 0.642 & *13.0 & 0.710 \\
\hline \multicolumn{12}{|l|}{ Age } \\
\hline $15-17$ years. . . . . . . . . . . . . . . . . . & 11,567 & ${ }^{\star} 3.2$ & 0.650 & ${ }^{*} 7.0$ & 0.788 & ${ }^{*} 1.1$ & 0.338 & ${ }^{*} 7.6$ & 0.776 & ${ }^{*} 9.9$ & 0.965 \\
\hline $18-19$ years. & 8,475 & 3.9 & 0.681 & 10.1 & 1.164 & 2.1 & 0.496 & 11.7 & 1.225 & 14.5 & 1.367 \\
\hline 20-24 years. & 19,723 & 5.3 & 0.654 & 11.5 & 1.139 & 1.8 & 0.458 & 13.1 & 1.140 & 16.5 & 1.235 \\
\hline 25-29 years. . . . . . . . . . . . . . & 18,475 & 2.6 & 0.406 & 8.8 & 0.970 & 0.7 & 0.200 & 9.1 & 0.947 & 10.9 & 1.024 \\
\hline 30-44 years. . . . . . . . . . . . . . & 64,467 & 2.2 & 0.249 & 8.3 & 0.507 & 1.6 & 0.262 & 9.4 & 0.597 & 10.7 & 0.623 \\
\hline \multicolumn{12}{|l|}{ Hispanic origin and race } \\
\hline $\begin{array}{l}\text { Hispanic or Latino . . . . . . . . . . . . . } \\
\text { Not Hispanic or Latino: }\end{array}$ & 19,295 & *4.1 & 0.598 & *10.5 & 0.721 & 1.9 & 0.434 & *12.1 & 0.826 & *14.8 & 1.033 \\
\hline Black or African Amercian, single race . . . . . & 15,190 & 5.3 & 0.487 & 16.0 & 1.027 & 2.1 & 0.363 & 17.2 & 1.125 & 20.4 & 1.202 \\
\hline Other single race or multiple race $\ldots \ldots \ldots$ & 9,986 & 3.1 & 0.696 & 8.2 & 1.392 & 2.3 & 0.828 & 9.7 & 1.415 & 10.7 & 1.480 \\
\hline \multicolumn{12}{|l|}{ Education ${ }^{1}$} \\
\hline Bachelor's degree or higher. . . . . & 25,452 & 2.1 & 0.328 & ${ }^{*} 6.7$ & 0.652 & ${ }^{*} 0.3$ & 0.106 & ${ }^{*} 6.8$ & 0.659 & *8.4 & 0.679 \\
\hline Some college, no bachelor's degree. & 27,382 & 2.7 & 0.427 & 9.0 & 0.792 & 1.2 & 0.415 & 9.9 & 0.909 & 11.4 & 0.879 \\
\hline High school diploma or GED $\ldots \ldots \ldots \ldots$ & 29,923 & 2.3 & 0.320 & 9.1 & 0.747 & 2.3 & 0.414 & 10.9 & 0.867 & 12.1 & 0.865 \\
\hline No high school diploma or GED $\ldots \ldots \ldots$ & 11,982 & 3.9 & 0.780 & 11.8 & 1.200 & 2.1 & 0.489 & 13.1 & 1.327 & 15.8 & 1.536 \\
\hline \multicolumn{12}{|l|}{ Percent of poverty level $\left.\right|^{2}$} \\
\hline 0-149 percent & 25,614 & *4.9 & 0.637 & ${ }^{*} 12.1$ & 0.943 & ${ }^{*} 2.4$ & 0.464 & *13.8 & 1.007 & *16.7 & 1.145 \\
\hline 150-299 percent. & 28,952 & 2.0 & 0.271 & 8.2 & 0.535 & 1.6 & 0.421 & 9.4 & 0.682 & 10.8 & 0.726 \\
\hline 300-399 percent $\ldots \ldots \ldots \ldots \ldots \ldots \ldots$ & 16,650 & 2.3 & 0.383 & 7.5 & 0.810 & 1.0 & 0.322 & 8.2 & 0.873 & 9.9 & 0.903 \\
\hline 400 percent or more $\ldots \ldots \ldots \ldots \ldots \ldots$ & 31,449 & 2.4 & 0.335 & 8.0 & 0.881 & 0.9 & 0.222 & 8.6 & 0.891 & 10.0 & 0.882 \\
\hline \multicolumn{12}{|l|}{ Region } \\
\hline Northeast & 18,065 & 3.3 & 0.357 & ${ }^{*} 9.5$ & 0.703 & ${ }^{*} 1.2$ & 0.273 & ${ }^{*} 10.1$ & 0.738 & 12.1 & 0.862 \\
\hline Midwest & 26,866 & 2.8 & 0.505 & 6.9 & 0.621 & 0.9 & 0.204 & 7.7 & 0.698 & 9.8 & 0.900 \\
\hline 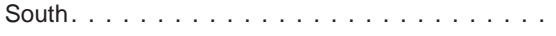 & 47,481 & 2.6 & 0.270 & 9.6 & 0.836 & 1.5 & 0.209 & 10.5 & 0.892 & 12.1 & 0.877 \\
\hline West $\ldots \ldots \ldots \ldots \ldots \ldots \ldots \ldots$ & 30,295 & 3.6 & 0.586 & 9.0 & 0.757 & 2.2 & 0.539 & 10.9 & 0.908 & 13.2 & 0.934 \\
\hline Central city 12 metropolitan areas & 16,851 & ${ }^{*} 3.8$ & 0.637 & *11.8 & 0.916 & 2.1 & 0.553 & *13.5 & 1.055 & *15.8 & 1.191 \\
\hline Central city other metropolitan areas & 28,273 & 4.0 & 0.459 & 11.6 & 1.238 & 1.7 & 0.233 & 12.6 & 1.239 & 15.0 & 1.133 \\
\hline Outside central city, 12 metropolitan areas. & 27,825 & 2.3 & 0.342 & 8.6 & 0.626 & 1.1 & 0.269 & 9.4 & 0.662 & 10.9 & 0.759 \\
\hline Outside central city, other metropolitan areas . . . & 27,495 & 2.5 & 0.469 & 6.4 & 0.658 & 1.3 & 0.443 & 7.4 & 0.904 & 9.4 & 1.052 \\
\hline Nonmetropolitan, urban areas. . . . . . . . . . . & 10,131 & 2.9 & 0.578 & 6.3 & 0.751 & 1.7 & 0.575 & 7.5 & 0.818 & 9.5 & 1.046 \\
\hline Nonmetropolitan, rural areas & 12,133 & 2.2 & 0.544 & 6.9 & 1.099 & 1.2 & 0.627 & 7.9 & 0.801 & 9.1 & 0.839 \\
\hline
\end{tabular}




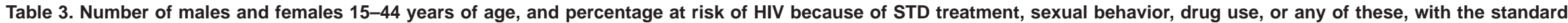
error of each percentage, by selected characteristics: United States, 2002-Con.

\begin{tabular}{|c|c|c|c|c|c|c|c|c|c|c|c|}
\hline \multirow[b]{2}{*}{ Characteristic } & \multirow{2}{*}{$\begin{array}{c}\text { Numbers } \\
\text { in } \\
\text { thousands }\end{array}$} & \multicolumn{2}{|c|}{ STD treatment in past year } & \multicolumn{2}{|c|}{$\begin{array}{l}\text { Risk from } \\
\text { sexual behavior }\end{array}$} & \multicolumn{2}{|c|}{ Risk from drug use } & \multicolumn{2}{|c|}{$\begin{array}{l}\text { Risk from sexual } \\
\text { behavior or drug use }\end{array}$} & \multicolumn{2}{|c|}{$\begin{array}{l}\text { Risk from sexual } \\
\text { behavior or drug } \\
\text { use or STD }\end{array}$} \\
\hline & & Percent & $\begin{array}{l}\text { Standard } \\
\text { error }\end{array}$ & Percent & $\begin{array}{l}\text { Standard } \\
\text { error }\end{array}$ & Percent & $\begin{array}{l}\text { Standard } \\
\text { error }\end{array}$ & Percent & $\begin{array}{l}\text { Standard } \\
\text { error }\end{array}$ & Percent & $\begin{array}{l}\text { Standard } \\
\text { error }\end{array}$ \\
\hline \multicolumn{12}{|l|}{ Incarceration status ${ }^{3}$} \\
\hline Ever incarcerated & 12,342 & *2.8 & 0.523 & *13.5 & 1.442 & ${ }^{*} 5.6$ & 1.125 & *17.1 & 1.736 & *18.1 & 1.693 \\
\hline Others ...... & 28,547 & 1.6 & 0.358 & 8.4 & 0.770 & 0.4 & 0.125 & 8.6 & 0.775 & 9.5 & 0.874 \\
\hline \multicolumn{12}{|l|}{ Military experience ${ }^{3}$} \\
\hline Ever in military & 5,214 & 1.4 & 0.730 & 8.8 & 1.598 & 4.4 & 2.038 & 11.5 & 2.378 & 11.8 & 2.352 \\
\hline Others $\ldots \ldots \ldots \ldots \ldots \ldots \ldots \ldots \ldots$ & 35,824 & 2.0 & 0.355 & 10.1 & 0.829 & 1.6 & 0.305 & 11.1 & 0.867 & 12.2 & 0.913 \\
\hline
\end{tabular}

*Within survey, categories are different; $p<.05$, Weighted Chi-Square statistically significant.

Limited to persons 22-44 years of age at time of interview. GED is General Educational Development diploma.

Limited to persons 20-44 years of age at time of interview.

Limited to males 25-44 years of age at time of interview.

SOURCE: National Survey of Family Growth Cycle 6 (2002). 
Table 4. Number of males and females 15-44 years of age and percentage at risk of HIV with the standard error of each percentage, by selected characteristics: United States, 2002

\begin{tabular}{|c|c|c|c|c|c|c|}
\hline \multirow[b]{3}{*}{ Characteristic } & \multicolumn{6}{|c|}{ Past year sex or drug risk or STD treatment } \\
\hline & \multicolumn{3}{|c|}{ Male } & \multicolumn{3}{|c|}{ Female } \\
\hline & $\begin{array}{l}\text { Numbers in } \\
\text { thousands }\end{array}$ & Percent & $\begin{array}{l}\text { Standard } \\
\text { error }\end{array}$ & $\begin{array}{l}\text { Numbers in } \\
\text { thousands }\end{array}$ & Percent & $\begin{array}{l}\text { Standard } \\
\text { error }\end{array}$ \\
\hline 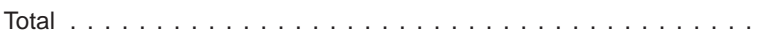 & 61,147 & 13.0 & 0.710 & 61,561 & 10.8 & 0.432 \\
\hline \multicolumn{7}{|l|}{ Age } \\
\hline $15-24$ years. . . . . . . . . . . . . . . . . . & 20,091 & 14.8 & 1.008 & 19,674 & *13.5 & 0.909 \\
\hline 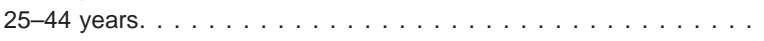 & 41,056 & 12.1 & 0.879 & 41,887 & 9.5 & 0.485 \\
\hline \multicolumn{7}{|l|}{ Hispanic origin and race } \\
\hline $\begin{array}{l}\text { Hispanic or Latino } \ldots \ldots \ldots \ldots \ldots \ldots \ldots \ldots \ldots \ldots \ldots \ldots \ldots \ldots \ldots \ldots \ldots \\
\text { Not Hispanic or Latino: }\end{array}$ & 10,188 & *17.6 & 1.591 & 9,107 & ${ }^{*} 11.7$ & 0.833 \\
\hline 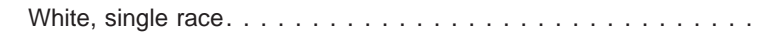 & 38,738 & 10.7 & 0.926 & 39,498 & 8.6 & 0.522 \\
\hline Black or African Amercian, single race $\ldots \ldots \ldots \ldots \ldots$ & 6,940 & 22.0 & 1.729 & 8,250 & 19.1 & 1.344 \\
\hline Other single race or multiple race $\ldots \ldots \ldots \ldots \ldots$ & 5,280 & 9.1 & 2.257 & 4,706 & 12.4 & 1.860 \\
\hline \multicolumn{7}{|l|}{ Education ${ }^{1}$} \\
\hline Bachelor's degree or higher $\ldots \ldots \ldots \ldots \ldots \ldots \ldots$ & 11,901 & 10.2 & 1.294 & 13,551 & *6.9 & 0.737 \\
\hline Some college, no bachelor's degree. . . . . . . . . . . . . & 13,104 & 12.6 & 1.534 & 14,279 & 10.3 & 0.767 \\
\hline High school diploma or GED . . . . . . . . . . . . . . . . . . & 15,659 & 13.6 & 1.323 & 14,264 & 10.4 & 1.039 \\
\hline No high school diploma or GED $\ldots \ldots \ldots \ldots \ldots \ldots \ldots$ & 6,355 & 15.9 & 2.476 & 5,627 & 15.6 & 1.552 \\
\hline \multicolumn{7}{|l|}{ Percent of poverty level ${ }^{2}$} \\
\hline 0-149 percent . . . . . . . . . . . . . . . . . . & 11,032 & ${ }^{*} 19.2$ & 2.072 & 14,582 & *14.9 & 1.109 \\
\hline 150-299 percent. . . . . . . . . . . . . . . . . . . . . & 14,451 & 12.4 & 1.204 & 14,502 & 9.3 & 0.752 \\
\hline 300 percent or more $\ldots \ldots \ldots \ldots \ldots \ldots \ldots \ldots$ & 25,457 & 11.5 & 0.956 & 22,643 & 8.2 & 0.732 \\
\hline \multicolumn{7}{|l|}{ Region } \\
\hline 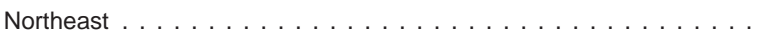 & 8,361 & 13.2 & 1.260 & 9,704 & 11.2 & 0.900 \\
\hline Midwest . . . . . . . . . . . . . . . . . & 12,766 & 10.2 & 1.187 & 14,100 & 9.4 & 0.900 \\
\hline 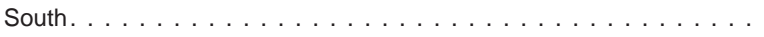 & 24,543 & 13.3 & 1.225 & 22,939 & 10.9 & 0.793 \\
\hline 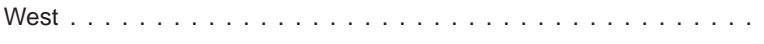 & 15,477 & 14.8 & 1.626 & 14,818 & 11.5 & 0.770 \\
\hline \multicolumn{7}{|l|}{ Metropolitan residence } \\
\hline Central city 12 metropolitan areas . . . . . . . . . . . . . & 8,313 & *17.9 & 1.534 & 8,538 & ${ }^{*} 13.8$ & 1.221 \\
\hline Central city other metropolitan areas $\ldots \ldots \ldots \ldots \ldots$ & 14,191 & 16.8 & 1.721 & 14,082 & 13.2 & 1.102 \\
\hline Outside central city, 12 metropolitan areas $\ldots \ldots \ldots \ldots$ & 13,844 & 11.7 & 0.955 & 13,981 & 10.0 & 1.050 \\
\hline Outside central city, other metropolitan areas $\ldots \ldots \ldots \ldots$ & 13,415 & 10.5 & 1.727 & 14,079 & 8.3 & 0.792 \\
\hline Nonmetropolitan, urban areas. . . . . . . . . . . . . . . . & 4,931 & 9.0 & 1.767 & 5,200 & 9.9 & 1.164 \\
\hline Nonmetropolitan, rural areas $\ldots \ldots \ldots \ldots \ldots \ldots$ & 6,453 & 9.3 & 1.928 & 5,680 & 8.8 & 1.438 \\
\hline
\end{tabular}

* Indicates that the differences in the percents between the categories of that variable are significant at the .05 level using a Weighted Chi-Square test.

${ }^{1}$ Limited to persons $22-44$ years of age at time of interview. GED is General Educational Development diploma.

${ }^{2}$ Limited to persons $20-44$ years of age at time of interview.

NOTE: STD is sexually transmitted disease.

SOURCE: National Survey of Family Growth Cycle 6 (2002). 
Table 5. Number of males and females 15-44 years of age and percentage at risk of HIV, with the standard error of the percentage, by Hispanic origin and race: United States, 2002

\begin{tabular}{|c|c|c|c|c|c|c|c|c|c|}
\hline \multirow[b]{2}{*}{ Hispanic origin and race } & \multicolumn{3}{|c|}{$\begin{array}{c}\text { Past year sex or drug } \\
\text { risk or STD treatment } \\
\text { Hispanic }\end{array}$} & \multicolumn{3}{|c|}{$\begin{array}{l}\text { Past year sex or drug risk } \\
\text { or STD treatment } \\
\text { non-Hispanic white }\end{array}$} & \multicolumn{3}{|c|}{$\begin{array}{l}\text { Past year sex or drug risk } \\
\text { or STD treatment } \\
\text { non-Hispanic black }\end{array}$} \\
\hline & $\begin{array}{l}\text { Numbers in } \\
\text { thousands }\end{array}$ & Percent & $\begin{array}{l}\text { Standard } \\
\text { error }\end{array}$ & $\begin{array}{l}\text { Numbers in } \\
\text { thousands }\end{array}$ & Percent & $\begin{array}{l}\text { Standard } \\
\text { error }\end{array}$ & $\begin{array}{l}\text { Numbers in } \\
\text { thousands }\end{array}$ & Percent & $\begin{array}{l}\text { Standard } \\
\text { error }\end{array}$ \\
\hline Total, both sexes. . . . . . . . . . . . . . . . . & 19,295 & 14.8 & 1.033 & 78,237 & 9.7 & 0.604 & 15,190 & 20.4 & 1.202 \\
\hline \multicolumn{10}{|l|}{ Sex } \\
\hline Male . . . . . . . . . . . . . . & 10,188 & *17.6 & 1.591 & 38,738 & *10.7 & 0.926 & 6,940 & 22.0 & 1.729 \\
\hline Female $\ldots \ldots \ldots \ldots \ldots \ldots \ldots \ldots$ & 9,107 & 11.7 & 0.833 & 39,498 & 8.6 & 0.522 & 8,250 & 19.1 & 1.344 \\
\hline \multicolumn{10}{|l|}{ Age } \\
\hline 15-24 years. . . . . . . . . . . . . . . . . & 6,732 & *18.1 & 1.763 & 24,318 & *11.5 & 0.946 & 5,355 & 22.1 & 2.082 \\
\hline 25-44 years. . . . . . . . . . . . . . . . & 12,563 & 13.0 & 1.148 & 53,919 & 8.8 & 0.651 & 9,835 & 19.6 & 1.320 \\
\hline \multicolumn{10}{|l|}{ Education ${ }^{1}$} \\
\hline Bachelor's degree or higher . . . . . . . . . . . . & 1,637 & 15.3 & 2.923 & 19,404 & 7.7 & 0.778 & 1,787 & *13.5 & 2.213 \\
\hline Some college, no bachelor's degree. . . . . . . . . & 3,128 & 12.1 & 1.667 & 18,333 & 10.5 & 1.213 & 3,517 & 16.5 & 1.850 \\
\hline High school diploma or GED . . . . . . . . . . . . & 4,705 & 14.8 & 1.662 & 18,555 & 8.3 & 1.095 & 4,603 & 23.9 & 2.468 \\
\hline No high school diploma or GED . . . . . . . . . . & 5,204 & 13.4 & 1.974 & 4,665 & 14.0 & 2.673 & 1,600 & 29.5 & 3.723 \\
\hline \multicolumn{10}{|l|}{ Percent of poverty level ${ }^{2}$} \\
\hline 0-149 percent . . . . . . . . . . . . . . . & 7,166 & 16.8 & 2.280 & 11,298 & 11.8 & 1.560 & 4,579 & *29.0 & 2.465 \\
\hline 150-299 percent. . . . . . . . . . . . . . . . . & 5,124 & 12.2 & 1.469 & 17,803 & 9.1 & 1.000 & 3,700 & 18.5 & 1.896 \\
\hline 300 percent or more $\ldots \ldots \ldots \ldots \ldots$ & 3,857 & 14.9 & 1.585 & 36,741 & 9.3 & 0.876 & 4,149 & 14.0 & 1.648 \\
\hline \multicolumn{10}{|l|}{ Region } \\
\hline Northeast . . . . . . . . . . . . . . . & 2,089 & *20.3 & 1.714 & 11,790 & 8.2 & 1.045 & 2,880 & *23.4 & 2.221 \\
\hline Midwest . . . . . . . . . . . . . . . & 1,446 & 10.0 & 3.320 & 21,069 & 8.3 & 0.872 & 2,848 & 23.2 & 3.567 \\
\hline South. . . . . . . . . . . . . . . . & 7,229 & 14.5 & 1.957 & 28,548 & 9.5 & 1.165 & 8,321 & 19.4 & 1.632 \\
\hline West . . . . . . . . . . . . . . . & 8,531 & 14.6 & 1.442 & 16,829 & 12.5 & 1.477 & 1,141 & 13.5 & 2.267 \\
\hline \multicolumn{10}{|l|}{ Metropolitan residence } \\
\hline Central city 12 metropolitan areas . . . . . . . . . & 5,487 & ${ }^{*} 17.1$ & 2.094 & 6,184 & *12.7 & 1.512 & 3,580 & 23.0 & 2.342 \\
\hline Central city other metropolitan areas $\ldots \ldots \ldots$ & 4,186 & 16.5 & 2.726 & 17,214 & 13.6 & 1.591 & 4,680 & 20.5 & 2.216 \\
\hline Outside central city, 12 metropolitan areas . . . . . & 5,577 & 13.4 & 1.371 & 16,631 & 8.6 & 0.834 & 3,420 & 19.5 & 2.578 \\
\hline Outside central city, other metropolitan areas . . . & 2,626 & 8.8 & 1.217 & 21,066 & 8.7 & 1.216 & 2,039 & 17.0 & 4.169 \\
\hline Nonmetropolitan, urban areas. . . . . . . . . . . . . & 754 & 13.5 & 4.574 & 8,189 & 7.8 & 1.083 & 513 & 22.3 & 6.946 \\
\hline Nonmetropolitan, rural areas $\ldots \ldots \ldots \ldots$ & 665 & 22.4 & 5.913 & 8,953 & 5.7 & 0.677 & 958 & 20.3 & 4.600 \\
\hline \multicolumn{10}{|l|}{ Incarceration status ${ }^{3}$} \\
\hline Ever incarcerated ..... & 1,854 & 13.5 & 2.395 & ${ }^{\star} 7,836$ & *16.0 & 2.325 & 1,612 & *33.6 & 3.703 \\
\hline Other . . . . . . . . . . . . . . . . . & 4,719 & 14.5 & 2.202 & 18,516 & 7.9 & 1.123 & 2,748 & 17.3 & 2.569 \\
\hline \multicolumn{10}{|l|}{ Military experience ${ }^{3}$} \\
\hline Ever in military . . . . . . . . . . . . . & 606 & 12.9 & 4.202 & 3,443 & 10.1 & 3.330 & 786 & 22.8 & 5.591 \\
\hline Other . . . . . . . . . . . . . . . & 6,002 & 14.4 & 1.964 & 22,967 & 10.4 & 1.192 & 3,604 & 23.3 & 2.750 \\
\hline
\end{tabular}

* Indicates that the differences in the percents between the categories of that variable are significant at the .05 level using a Weighted Chi-Square test.

${ }^{1}$ Limited to persons 22-44 years of age at time of interview. GED is General Educational Development diploma.

${ }^{2}$ Limited to persons $20-44$ years of age at time of interview.

${ }^{3}$ Limited to males $25-44$ years of age at time of interview.

NOTE: STD is sexually transmitted disease.

SOURCE: National Survey of Family Growth Cycle 6 (2002). 
Table 6. Number of persons 15-44 years of age and percentage never tested for HIV with the standard error of the percentage, by type of risk for HIV: United States, 2002

\begin{tabular}{|c|c|c|c|c|c|c|c|c|c|}
\hline \multirow[b]{2}{*}{ Risk for HIV } & \multicolumn{3}{|c|}{ Both sexes } & \multicolumn{3}{|c|}{ Male } & \multicolumn{3}{|c|}{ Female } \\
\hline & $\begin{array}{l}\text { Numbers in } \\
\text { thousands }\end{array}$ & Percent & $\begin{array}{l}\text { Standard } \\
\text { error }\end{array}$ & $\begin{array}{l}\text { Numbers in } \\
\text { thousands }\end{array}$ & Percent & $\begin{array}{l}\text { Standard } \\
\text { error }\end{array}$ & $\begin{array}{l}\text { Numbers in } \\
\text { thousands }\end{array}$ & Percent & $\begin{array}{c}\text { Standard } \\
\text { error }\end{array}$ \\
\hline Total . . . . . . . . . . . . . . . . & 122,708 & 49.3 & 0.806 & 61,147 & 53.4 & 1.232 & 61,561 & 45.1 & 0.881 \\
\hline STD treatment in past year ${ }^{1} \ldots \ldots$ & 3,650 & *25.9 & 3.002 & 1,575 & *23.9 & 5.307 & 2,075 & *27.4 & 3.682 \\
\hline Others . . . . . . . . . . . . . . & 118,549 & 50.0 & 0.806 & 59,303 & 54.2 & 1.244 & 59,246 & 45.8 & 0.886 \\
\hline Drug injection or crack use $\ldots \ldots \ldots$ & 1,843 & *27.6 & 4.357 & 1,233 & *30.1 & 5.584 & 610 & *22.4 & 6.004 \\
\hline Others $\ldots \ldots \ldots \ldots \ldots \ldots \ldots$ & 120,491 & 49.6 & 0.793 & 59,694 & 54.0 & 1.221 & 60,798 & 45.4 & 0.881 \\
\hline Male-to-male sex . . . . . . . . . & $\ldots$ & $\ldots$ & $\ldots$ & 1,651 & *30.9 & 4.042 & $\ldots$ & $\ldots$ & $\ldots$ \\
\hline Others $\ldots \ldots \ldots \ldots \ldots \ldots$ & $\cdots$ & $\cdots$ & $\cdots$ & 58,719 & 53.9 & 1.282 & $\cdots$ & $\cdots$ & $\cdots$ \\
\hline Females with MSM partner ${ }^{2} \ldots \ldots$. . & $\ldots$ & $\ldots$ & $\ldots$ & $\ldots$ & $\ldots$ & $\ldots$ & 1,405 & *29.0 & 4.739 \\
\hline Others $\ldots \ldots \ldots \ldots \ldots \ldots$ & $\cdots$ & $\cdots$ & $\cdots$ & $\cdots$ & $\cdots$ & $\cdots$ & 59,468 & 45.5 & 0.874 \\
\hline 5 or more opposite sex partners . . . . & 4,265 & *35.7 & 3.357 & 2,801 & *38.3 & 4.103 & 1,464 & *30.8 & 4.431 \\
\hline Others . . . . . . . . . . . . . & 117,742 & 49.7 & 0.816 & 57,924 & 54.1 & 1.248 & 59,818 & 45.4 & 0.888 \\
\hline Any IDU sex partners ${ }^{3} \ldots \ldots \ldots \ldots$ & 3,186 & *39.0 & 3.647 & 1,386 & 46.1 & 6.529 & 1,801 & *33.6 & 3.996 \\
\hline Others . . . . . . . . . . . . . . & 118,831 & 49.6 & 0.815 & 59,462 & 53.6 & 1.293 & 59,369 & 45.5 & 0.879 \\
\hline Exchange sex for drugs or money. . . & 2,821 & *33.0 & 3.227 & 1,572 & *38.5 & 4.428 & 1,249 & *25.9 & 4.203 \\
\hline Others . . . . . . . . . . . . . & 119,357 & 49.6 & 0.812 & 59,308 & 53.8 & 1.261 & 60,050 & 45.5 & 0.869 \\
\hline Any sexual risk behavior . . . . . . . . & 10,734 & *35.1 & 1.798 & 6,106 & *37.7 & 2.401 & 4,629 & *31.6 & 2.524 \\
\hline Others . . . . . . . . . . . . . & 110,197 & 50.5 & 0.831 & 53,974 & 54.9 & 1.362 & 56,222 & 46.3 & 0.889 \\
\hline Any sex or drug risk behavior. . . . . & 12,015 & *34.4 & 1.802 & 6,953 & *36.8 & 2.433 & 5,063 & *31.1 & 2.334 \\
\hline Others . . . . . . . . . . . . . . & 108,848 & 50.8 & 0.815 & 53,124 & 55.3 & 1.346 & 55,724 & 46.4 & 0.880 \\
\hline $\begin{array}{l}\text { Sex or drug risk, or STD treatment in } \\
\text { past year }{ }^{1} \ldots \ldots \ldots \ldots \ldots \ldots \ldots\end{array}$ & 14,358 & *33.6 & 1.677 & 7,809 & *36.0 & 2.339 & 6,549 & *30.7 & 2.103 \\
\hline Others . . . . . . . . . . . . . & 106,580 & 51.2 & 0.819 & 52,282 & 55.7 & 1.361 & 54,297 & 46.8 & 0.880 \\
\hline
\end{tabular}

* Indicates that the differences between risk categories and others are significant at the $p<.05$, using a Weighted Chi-Square test. ... Category not applicable.

${ }^{1}$ STD is sexually transmitted disease.

${ }^{2} \mathrm{MSM}$ is men who have sex with men.

${ }^{3}$ IDU is injecting drug user.

SOURCE: National Survey of Family Growth Cycle 6 (2002). 
Table 7. Number of persons 15-44 years of age who had at least one sexual partner in the past 12 months, and percentage who used a condom at their last sexual encounter, by type of risk for HIV: United States, 2002

\begin{tabular}{|c|c|c|c|c|c|c|c|c|c|}
\hline \multirow[b]{2}{*}{ Risk for HIV } & \multicolumn{3}{|c|}{ Both sexes } & \multicolumn{3}{|c|}{ Male } & \multicolumn{3}{|c|}{ Female } \\
\hline & $\begin{array}{l}\text { Numbers in } \\
\text { thousands }\end{array}$ & Percent & $\begin{array}{c}\text { Standard } \\
\text { error }\end{array}$ & $\begin{array}{l}\text { Numbers in } \\
\text { thousands }\end{array}$ & Percent & $\begin{array}{l}\text { Standard } \\
\text { error }\end{array}$ & $\begin{array}{l}\text { Numbers in } \\
\text { thousands }\end{array}$ & Percent & $\begin{array}{c}\text { Standard } \\
\text { error }\end{array}$ \\
\hline Total . . . . . . . . . . . . . . . & 99,906 & 27.7 & 0.655 & 50,510 & 30.3 & 0.987 & 49,396 & 24.9 & 0.723 \\
\hline STD treatment in past year ${ }^{1} \ldots \ldots$ & 3,314 & *41.1 & 3.099 & 1,391 & *52.5 & 6.480 & 1,923 & *32.9 & 3.081 \\
\hline Others . . . . . . . . . . . & 96,592 & 27.2 & 0.665 & 49,119 & 29.6 & 1.006 & 47,473 & 24.6 & 0.748 \\
\hline Drug injection or crack use $\ldots \ldots \ldots$ & 1,640 & 23.4 & 3.199 & 1,088 & 24.5 & 4.270 & 552 & 21.2 & 4.672 \\
\hline Others . . . . . . . . . . . . & 98,258 & 27.7 & 0.663 & 49,419 & 30.4 & 0.989 & 48,840 & 25.0 & 0.726 \\
\hline Male-to-male sex $\ldots \ldots \ldots \ldots \ldots$ & $\ldots$ & $\ldots$ & $\ldots$ & 1,651 & *52.4 & 4.807 & $\ldots$ & $\ldots$ & $\ldots$ \\
\hline Others $\ldots \ldots \ldots \ldots \ldots \ldots \ldots$ & $\ldots$ & $\ldots$ & $\ldots$ & 48,636 & 29.4 & 0.993 & $\ldots$ & $\ldots$ & $\ldots$ \\
\hline Females with MSM partner ${ }^{2} \ldots \ldots$. . & $\cdots$ & $\ldots$ & $\ldots$ & $\ldots$ & $\ldots$ & $\ldots$ & 1,350 & *38.1 & 4.412 \\
\hline Others $\ldots \ldots \ldots \ldots \ldots \ldots$ & $\ldots$ & $\cdots$ & $\ldots$ & $\cdots$ & $\cdots$ & $\ldots$ & 47,624 & 24.3 & 0.749 \\
\hline 5 or more opposite sex partners . . . & 4,201 & *50.9 & 3.189 & 2,801 & *58.5 & 4.010 & 1,401 & *35.7 & 4.311 \\
\hline Others . . . . . . . . . . . . & 95,755 & 26.6 & 0.653 & 47,747 & 28.7 & 0.982 & 48,008 & 24.6 & 0.737 \\
\hline Any IDU sex partners ${ }^{3}$. & 3,116 & 31.7 & 3.608 & 1,369 & 38.4 & 6.083 & 1,747 & 26.4 & 4.176 \\
\hline Others $\ldots \ldots \ldots \ldots \ldots \ldots$ & 96,655 & 27.5 & 0.670 & 49,132 & 30.1 & 1.020 & 47,524 & 24.8 & 0.735 \\
\hline Exchange sex for drugs or money. . . & 2,773 & *42.3 & 3.232 & 1,556 & *49.4 & 4.996 & 1,216 & 33.2 & 5.053 \\
\hline Others . . . . . . . . . . . . & 97,153 & 27.2 & 0.659 & 48,969 & 29.7 & 1.004 & 48,184 & 24.7 & 0.731 \\
\hline Any sexual risk behavior . . . . . . . . & 10,541 & *43.2 & 1.807 & 6,079 & *50.0 & 2.676 & 4,462 & *34.0 & 2.882 \\
\hline others $\ldots \ldots \ldots \ldots \ldots \ldots$ & 88,740 & 25.6 & 0.690 & 44,228 & 27.5 & 1.031 & 44,512 & 23.8 & 0.762 \\
\hline Any sex or drug risk behavior. . . . . . & 11,623 & *40.6 & 1.749 & 6,780 & *46.3 & 2.537 & 4,843 & *32.5 & 2.706 \\
\hline Others . . . . . . . . . . . . & 87,632 & 25.8 & 0.698 & 43,498 & 27.7 & 1.031 & 44,134 & 23.9 & 0.766 \\
\hline Sex or drug risk, or STD treatment . . & 13,637 & *39.6 & 1.500 & 7,457 & *45.5 & 2.349 & 6,180 & *32.5 & 2.158 \\
\hline Others . . . . . . . . . . . . & 85,673 & 25.6 & 0.700 & 42,826 & 27.5 & 1.049 & 42,847 & 23.6 & 0.775 \\
\hline
\end{tabular}

* Indicates that the differences between risk categories and others are significant at the $p<.05$, using a Weighted Chi-Square test.

.... Category not applicable.

${ }^{1}$ STD is sexually transmitted disease.

${ }^{2} \mathrm{MSM}$ is men who have sex with men.

${ }^{3}$ IDU is injecting drug user.

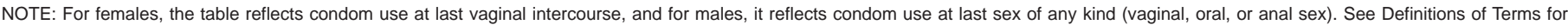
further details.

SOURCE: National Survey of Family Growth Cycle 6 (2002). 
Table 8. Estimated percentage with standard error of persons 15-44 years of age using drugs in the past year, by type of drug use, sex, and Hispanic origin and race, from the Cycle 6 National Survey of Family Growth and the National Survey of Drug Use and Health: United States, 2002

\begin{tabular}{|c|c|c|c|c|c|}
\hline \multirow[b]{2}{*}{ Characteristic } & \multicolumn{2}{|c|}{2002 NSFG } & \multicolumn{2}{|c|}{2002 NSDUH } & \multirow{2}{*}{$\begin{array}{c}\text { Difference } \\
\text { between } \\
\text { survey } \\
\text { estimates }\end{array}$} \\
\hline & Percent & $\begin{array}{l}\text { Standard } \\
\text { error }\end{array}$ & Percent & $\begin{array}{l}\text { Standard } \\
\text { error }\end{array}$ & \\
\hline \multicolumn{6}{|l|}{ A. Past year drug injection } \\
\hline Total . . . & 0.4 & 0.068 & 0.2 & 0.039 & 0.2 \\
\hline \multicolumn{6}{|l|}{ Sex: } \\
\hline Male $\ldots \ldots \ldots \ldots \ldots \ldots \ldots$ & 0.5 & 0.116 & 0.3 & 0.067 & 0.2 \\
\hline 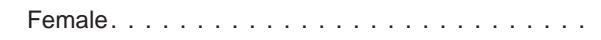 & 0.3 & 0.087 & 0.2 & 0.041 & 0.2 \\
\hline \multicolumn{6}{|l|}{ Hispanic origin and race: } \\
\hline Non-Hispanic white $\ldots \ldots \ldots \ldots \ldots \ldots$ & 0.4 & 0.081 & 0.3 & 0.056 & 0.1 \\
\hline Non-Hispanic black $\ldots \ldots \ldots \ldots \ldots \ldots \ldots$ & 0.6 & 0.266 & 0.2 & 0.116 & 0.4 \\
\hline Hispanic $\ldots \ldots \ldots \ldots \ldots \ldots \ldots \ldots$ & 0.5 & 0.143 & 0.1 & 0.050 & 0.4 \\
\hline Other. . & 0.2 & 0.117 & 0.1 & 0.079 & 0.1 \\
\hline \multicolumn{6}{|l|}{ B. Any crack use in past year } \\
\hline Total . . . . . . . . . . . . . . . . . . & 1.3 & 0.156 & 0.9 & 0.086 & 0.3 \\
\hline \multicolumn{6}{|l|}{ Sex: } \\
\hline Male & *1.8 & 0.274 & *1.3 & 0.153 & 0.5 \\
\hline 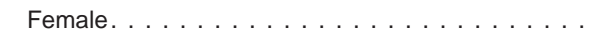 & 0.8 & 0.149 & 0.6 & 0.080 & 0.2 \\
\hline \multicolumn{6}{|l|}{ Hispanic origin and race: } \\
\hline Non-Hispanic white $\ldots \ldots \ldots \ldots \ldots \ldots$ & 1.0 & 0.183 & 0.9 & 0.094 & 0.0 \\
\hline Non-Hispanic black $\ldots \ldots \ldots \ldots \ldots \ldots \ldots$ & 1.8 & 0.352 & 1.5 & 0.360 & 0.2 \\
\hline Hispanic $\ldots \ldots \ldots \ldots \ldots \ldots \ldots \ldots$ & 1.6 & 0.398 & 0.6 & 0.218 & 1.0 \\
\hline Other $\ldots \ldots \ldots \ldots \ldots \ldots \ldots \ldots$ & 2.1 & 0.748 & 0.8 & 0.266 & 1.4 \\
\hline \multicolumn{6}{|l|}{ C. Any injection or crack use in past year } \\
\hline 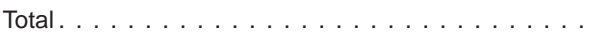 & 1.5 & 0.167 & 1.1 & 0.091 & 0.4 \\
\hline \multicolumn{6}{|l|}{ Sex: } \\
\hline$\ldots \ldots \ldots \ldots \ldots$ & ${ }^{*} 2.0$ & 0.293 & *1.5 & 0.160 & 0.6 \\
\hline 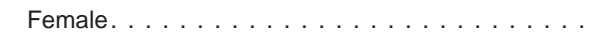 & 1.0 & 0.164 & 0.7 & 0.088 & 0.3 \\
\hline \multicolumn{6}{|l|}{ Hispanic origin and race: } \\
\hline Non-Hispanic white $\ldots \ldots \ldots \ldots \ldots \ldots \ldots$ & 1.2 & 0.194 & 1.1 & 0.105 & 0.1 \\
\hline Non-Hispanic black $\ldots \ldots \ldots \ldots \ldots \ldots \ldots$ & 2.1 & 0.363 & 1.6 & 0.361 & 0.5 \\
\hline Hispanic $\ldots \ldots \ldots \ldots \ldots \ldots \ldots$ & 1.9 & 0.434 & 0.7 & 0.222 & 1.2 \\
\hline Other $\ldots \ldots \ldots \ldots \ldots \ldots \ldots \ldots \ldots$ & 2.3 & 0.828 & 0.8 & 0.266 & 1.5 \\
\hline
\end{tabular}

* Within a survey, categories are different at the .05 level with a Weighted Chi-Square. Statistically significant differences between surveys are shown in bold.

NOTES: National Survey of Family Growth is NSFG $(n=12,571)$. National Survey of Drug Use and Health is NSDUH ( $n=32,247)$. 
Table 9. Percentage of persons 18-44 years of age reporting selected sexual behaviors in the past year the standard errors of each percentage in the 2002 National Survey of Family Growth and the 2000-02 General Social Survey, and the difference in the survey estimates: United States

\begin{tabular}{|c|c|c|c|c|c|c|c|}
\hline \multirow[b]{2}{*}{ Sex and race and ethnicity } & \multicolumn{3}{|c|}{2002 NSFG } & \multicolumn{3}{|c|}{ 2000-02 GSS } & \multirow[b]{2}{*}{ Difference } \\
\hline & Percent & $\begin{array}{l}\text { Standard } \\
\text { error }\end{array}$ & $\begin{array}{l}\text { Unweighted } \\
\text { number }\end{array}$ & Percent & $\begin{array}{l}\text { Standard } \\
\text { error }\end{array}$ & $\begin{array}{l}\text { Unweighted } \\
\text { number }\end{array}$ & \\
\hline \multicolumn{8}{|l|}{ A. 2 or more opposite sex partners in past year } \\
\hline Total. & 16.6 & 0.603 & 11,181 & 19.3 & 1.118 & 2,461 & -2.7 \\
\hline \multicolumn{8}{|l|}{ Sex: } \\
\hline 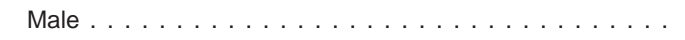 & *18.8 & 0.876 & 4,251 & *25.7 & 1.831 & 1,124 & -6.9 \\
\hline Female $\ldots \ldots \ldots \ldots \ldots \ldots \ldots \ldots \ldots$ & 14.5 & 0.668 & 6,930 & 13.5 & 1.293 & 1,337 & 1.0 \\
\hline \multicolumn{8}{|l|}{ Hispanic origin and race: } \\
\hline Non-Hispanic white $\ldots \ldots \ldots \ldots \ldots \ldots \ldots \ldots$ & *14.7 & 0.766 & 5,992 & *18.0 & 1.295 & 1,743 & -3.2 \\
\hline Non-Hispanic black . . . . . . . . . . . . . . & 27.7 & 1.535 & 2,181 & 25.3 & 3.200 & 371 & 2.4 \\
\hline Hispanic. . . . . . . . . . . . . . . . . . & 17.8 & 1.002 & 2,427 & 23.8 & 3.810 & 248 & -5.9 \\
\hline$\ldots \ldots \ldots \ldots \ldots \ldots \ldots$ & 10.6 & 1.507 & 581 & 11.2 & 4.503 & 97 & -0.6 \\
\hline \multicolumn{8}{|l|}{ B. 5 or more opposite sex partners in past year } \\
\hline Total. . . . . . . . . . . . . . . . . . . . & 3.6 & 0.268 & 11,181 & 3.1 & 0.494 & 2,461 & 0.4 \\
\hline \multicolumn{8}{|l|}{ Sex: } \\
\hline${ }_{1-2}$ & *4.8 & 0.414 & 4,251 & ${ }^{*} 5.9$ & 0.977 & 1,124 & -1.2 \\
\hline Female $\ldots \ldots \ldots \ldots \ldots \ldots \ldots \ldots \ldots$ & 2.4 & 0.262 & 6,930 & 0.7 & 0.300 & 1,337 & 1.7 \\
\hline \multicolumn{8}{|l|}{ Hispanic origin and race: } \\
\hline Non-Hispanic white $\ldots \ldots \ldots \ldots \ldots \ldots \ldots$. . . . . . . . . & *2.6 & 0.338 & 5,992 & 2.8 & 0.550 & 1,743 & -0.2 \\
\hline Non-Hispanic black . . . . . . . . . . . . . . . . . . . . & 7.8 & 0.973 & 2,181 & 5.0 & 1.701 & 371 & 2.8 \\
\hline Hispanic. . . . . . . . . . . . . . . . . & 4.5 & 0.518 & 2,427 & 4.0 & 1.702 & 248 & 0.5 \\
\hline Other. $\ldots \ldots \ldots \ldots \ldots \ldots \ldots \ldots$ & 2.5 & 0.808 & 581 & 1.0 & 1.264 & 97 & 1.5 \\
\hline \multicolumn{8}{|l|}{ C. Male sex partner in past year, males only } \\
\hline 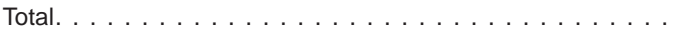 & 2.8 & 0.352 & 4,225 & 4.5 & 0.871 & 1,002 & 1.7 \\
\hline \multicolumn{8}{|l|}{ Hispanic origin and race: } \\
\hline Non-Hispanic white . . . . . . . . . . . . . . . . . . . . . & 2.7 & 0.452 & 2,223 & 4.1 & 0.962 & 738 & 1.4 \\
\hline Non-Hispanic black . . . . . . . . . . . . . . & 3.3 & 0.809 & 800 & 6.2 & 2.713 & 129 & 2.9 \\
\hline Hispanic. . . . . . . . . . . . . . . . . & 3.0 & 0.512 & 968 & 6.2 & 3.445 & 99 & 3.2 \\
\hline Other. . . . & 1.7 & 1.095 & 234 & 2.6 & 3.345 & 34 & 0.9 \\
\hline
\end{tabular}

* Within survey, categories are different; $p<.05$, Weighted Chi-Square statistically significant; differences between surveys shown in bold.

NOTE: NSFG is National Survey of Family Growth and GSS is General Social Survey.

Table 10. Percentage of persons 18-44 years of age reporting treatment for Sexually Transmitted Disease in the 2002 National Survey of Family Growth and in the 2002 National Health Interview Survey, by sex and Hispanic origin and race: United States, 2002

\begin{tabular}{|c|c|c|c|c|c|c|c|}
\hline \multirow[b]{2}{*}{ Sex and race and ethnicity } & \multicolumn{3}{|c|}{2002 NSFG: STD treatment in past year } & \multicolumn{3}{|c|}{2002 NHIS: STD in past 5 years } & \multirow[b]{2}{*}{ Difference } \\
\hline & Percent & $\begin{array}{l}\text { Standard } \\
\text { error }\end{array}$ & $\begin{array}{l}\text { Unweighted } \\
\text { number }\end{array}$ & Percent & $\begin{array}{l}\text { Standard } \\
\text { error }\end{array}$ & $\begin{array}{l}\text { Unweighted } \\
\text { number }\end{array}$ & \\
\hline Total . . . . . . . . . . . . . . . . . . . . . & 3.0 & 0.214 & 11,210 & 2.2 & 0.134 & 15,722 & 0.8 \\
\hline \multicolumn{8}{|l|}{ Sex } \\
\hline Male . . . . . . . . . . . . . . . . . & 2.7 & 0.316 & 4,267 & *1.6 & 0.162 & 7,042 & 1.1 \\
\hline Female $\ldots \ldots \ldots \ldots \ldots \ldots \ldots$ & 3.3 & 0.209 & 6,943 & 2.7 & 0.203 & *8,680 & 0.6 \\
\hline \multicolumn{8}{|l|}{ Hispanic origin and race } \\
\hline Non-Hispanic white . . . . . . . . . . . . . & *2.2 & 0.246 & 6,009 & *2.1 & 0.176 & 9,209 & 0.1 \\
\hline Non-Hispanic black . . . . . . . . . . . . . . . . & 5.1 & 0.432 & 2,185 & 3.8 & 0.385 & 2,300 & 1.3 \\
\hline Hispanic. . . . . . . . . . . . . . . . . . . & 4.4 & 0.643 & 2,435 & 1.7 & 0.252 & 3,495 & 2.7 \\
\hline Other $\ldots \ldots \ldots \ldots \ldots \ldots \ldots \ldots$ & 3.1 & 0.904 & 581 & 0.7 & 0.270 & 718 & 2.4 \\
\hline
\end{tabular}

* Within survey, categories are different; $\mathrm{p}<.05$, Weighted Chi-Square statistically significant; differences between surveys shown in bold.

NOTES: NSFG is National Survey of Family Growth $(n=11,210)$. NHIS is National Health Interview Survey $(n=15,722)$. 


\section{Technical Notes}

\section{Computing confidence intervals from standard errors}

The tables contain estimates of percentages and the standard error of these percentages. Percentages presented here are ratio estimates and the actual confidence intervals for these estimates will tend to be slightly asymmetrical, particularly for percentages near 0 or 100 (53).

To compute the confidence intervals, follow the steps listed below (54):

1. Convert the percentage to a proportion ("p") by dividing by 100 and convert its standard error to the standard error of the proportion ("se") by dividing it by 100 .

2. Compute the logit transformation of $p$, referred to as $f(p)$ :

$$
f(p)=\ln (p)-\ln (1-p) \text {. }
$$

3. Compute the standard error of the logit estimate:

$$
s[f(p)]=s e / p(1-p)
$$

4. The lower and upper confidence limits of the logit estimate ("Lf" and "Uf") are given by:

$$
\begin{aligned}
& \mathrm{Lf}=\mathrm{f}(\mathrm{p})-\mathrm{t}_{\mathrm{a} / 2} * s[\mathrm{f}(\mathrm{p})] \\
& \mathrm{Uf}=\mathrm{f}(\mathrm{p})+\mathrm{t}_{\mathrm{a} / 2} * \mathrm{~s}[\mathrm{f}(\mathrm{p})]
\end{aligned}
$$

where $t_{a / 2}$ is value from the $t$ distribution for a given level of alpha and degrees of freedom, for example, 1.96 for 2-tailed test with alpha=.05 and a large sample.

5. The next step is to convert the limits of the confidence interval of the logit to an interval for the proportion ("Lp" and "Up").

$$
\begin{aligned}
& \mathrm{Lp}=\exp (\mathrm{Lf}) /(1+\exp (\mathrm{Lf})) \\
& \mathrm{Up}=\exp (\mathrm{Uf}) /(1+\exp (\mathrm{Uf}))
\end{aligned}
$$

6. Finally, multiplying these values by 100 will convert the upper and lower limits to percentages.

The percentage of male respondents who reported five or more sex partners in the past year can be used as an example; this percentage for males is 4.6 and the standard error is 0.387 , as shown in Table 1.

1. Converting these to proportions by dividing by 100 yields estimates of
0.046 and 0.00387 for the proportion and its standard error.

2. The logit transformation is $f(p)=\ln (.046)-\ln (1-.046)=-3.032$.

3 . The standard error of the logit estimate:

$$
\begin{aligned}
& \mathrm{s}[\mathrm{f}(\mathrm{p})]=.00387 /((.046) \\
& (1-.046))=.088 .
\end{aligned}
$$

4. The lower and upper confidence limits of the logit estimate ("Lf" and "Uf") for a 95 percent confidence are:

Lf $=-3.032-1.96 * .088=-3.205$

$\mathrm{Uf}=-3.032+1.96 * .088=-2.859$

5. The lower and upper confidence limits for the logit can be transformed to limits for a proportion by exponentiation and dividing appropriately:

$\mathrm{Lp}=\exp (-3.205) /(1+\exp (-3.205))=0.039$. $\mathrm{Up}=\exp (-2.859) /(1+\exp (-2.859))=0.054$.

6. Finally, multiplying these values by 100 will convert the upper and lower limits to percentages, 3.9 and 5.4 percent.

In this example, the estimated 95 percent confidence interval around the point estimate of 4.6 percent would be 3.9-5.4 percent. Generally, confidence intervals will be more asymmetrical for values below 10 percent and above 90 percent. In cases where the lower bound of the confidence interval is negative, or the upper bound would exceed 1.0, the logit transformation is suggested.

\section{Sample design and fieldwork procedures}

Cycle 6 of the National Survey of Family Growth, or NSFG, was based on 12,571 interviews with men and women 15-44 years of age in the household population of the United States. The interviews were administered in person by trained female interviewers in the selected persons' homes. The Cycle 6 sample is a nationally representative multistage area probability sample drawn from 121 areas across the country. The sample is designed to produce national, not state, estimates.

Persons were selected for the NSFG in five major steps:
- Large areas (counties and cities) were chosen first.

- Within each large area or "primary sampling unit," groups of adjacent blocks, called segments, were chosen at random.

- Within segments, addresses were listed and some addresses were selected at random.

- The selected addresses were visited in person, and a short "screener" interview was conducted to see if anyone $15-44$ years of age lived there.

- If so, one person was chosen at random for the interview and was offered a chance to participate.

To protect the respondent's privacy, only one person was interviewed in each selected household. In Cycle 6, teenagers and black and Hispanic adults were sampled at higher rates than others.

The NSFG questionnaires and materials were reviewed and approved by the NCHS/CDC Research Ethics Review Board (formerly known as an Institutional Review Board or IRB), and by a similar board at the University of Michigan. The female questionnaire lasted an average of about 85 minutes, and the male questionnaire lasted an average of 60 minutes. All respondents were given written and oral information about the survey and were informed that participation was voluntary. Adult respondents 18-44 years of age were asked to sign a consent form but were not required to do so. For minors 1517 years of age, signed consent was required first from a parent or guardian, and then signed assent was required from the minor. The response rate for the survey was 79 percent-about 80 percent for women and 78 percent for men.

Over 200 female interviewers were hired and trained by the survey contractor, the University of Michigan's Institute for Social Research, under the supervision of NCHS. Interviewing occurred from March 2002 through February 2003. The demographic characteristics in this report were collected by computer-assisted personal interviewing, or CAPI. The questionnaires were programmed into 
laptop computers and administered by an interviewer. The measures of sexual behaviors and drug use, however, were collected by Audio Computer-Assisted Self-Interviewing, or ACASI, in which the person being interviewed reads the question and response categories on a computer screen (or hears them through headphones) and then enters his or her response directly into a computer.

ACASI provides greater privacy for the respondent.

Respondents in the Cycle 6 survey were offered $\$ 40$ as a "token of appreciation" for their participation. More detailed information about the methods and procedures of the study have been published in a separate report (30).

In this report, each percentage estimate is shown with its standard error and an estimate of the number of persons in the population in this category.

Readers should pay close attention to the relative size of the standard error for small groups, for example, separate race and ethnic categories shown for metropolitan status residential categories.

The measures of risk behaviors in this report are based on a reference period of the 12 months before interview, specified in the actual wording of the questions, for example, for male respondents interviewed in June 2002, the question would read, "Thinking about the last 12 months, that is, since June 2001, how many female sex partners have you had?"

\section{Definitions of terms}

ACASI-Audio Computer-Assisted Self-Interviewing. A data collection method in which the respondent reads the question and response categories on a computer screen (or hears them through headphones) and then enters his/her response directly into a computer, providing greater privacy for the respondent. Because ACASI presents the appropriate questions to the respondent, it also reduces the amount of missing data compared with paper and pencil self-administered questionnaires. Most of the data on sexual behavior in this report were collected using ACASI.
Age (recode $=A G E R)$ - In this report, "age" is classified based on the respondent's age as of the date of the interview as reported in CAPI. Sampled persons were eligible for the Cycle 6 NSFG if they were 15-44 years of age at the time of the household screener, and with the exception of a few respondents who may have turned 45 by the time of interview, all were still 1544 at interview.

Education: highest grade or degree ( recode $=$ HIEDUC) — This is based on a series of questions that measure the highest degree received as well as the highest grade or year of school completed. The categories of HIEDUC were defined as follows:

- No high school diploma or general equivalency diploma (GED): The person interviewed has not received a high school degree, GED, or college diploma.

- High school diploma or GED: The highest degree obtained is a high school diploma or GED, and his or her highest completed grade of school is 12 or lower.

- Some college, no bachelor's degree: The highest degree the man or woman obtained is a high school diploma or GED, but the highest grade of school completed is higher than 12 , or the highest degree is an associate's degree.

- Bachelor's degree or higher: The person reported having a college or university degree at the bachelor's level or higher, regardless of highest grade completed.

The tables in this report show data by education only for those 22-44 years of age, because large percentages of those 15-21 years of age are still attending school. Using the full age range of 15-44 would understate the eventual educational attainment of those 15-21 years of age.

Ever been in jail, prison, or juvenile detention center-In ACASI, male respondents were asked:

"Have you ever spent time in a jail, prison, or juvenile detention center?"

In this report, statistics are shown for males 25-44 years of age because the most common age at incarceration is in the 20s; using the 15-44 age range would mean that the "never been in jail or prison" category would contain proportionately more teenage respondents. This question on jail or prison time was not asked of female respondents in the NSFG because incarceration rates for women are lower than they are for men, and the NSFG is not large enough to produce reliable estimates of women who have been incarcerated.

Hispanic origin and race (based on the CAPI recode HISPRACE and raw variable NUMRACE)_The recode HISPRACE provided on the public-use file classifies respondents as Hispanic, Non-Hispanic white, Non-Hispanic black, or Non-Hispanic other race, based on two other recoded variables, HISPANIC and RACE. All respondents who answered "yes" to the following question were coded as "Hispanic":

"Are you Hispanic or Latino, or of Spanish origin?"

The RACE recode was based on the following question:

"Which of the following groups describe your racial background? Please select one or more groups."

The racial groups shown were:

- American Indian or Alaskan Native

- Asian

- Native Hawaiian or other Pacific Islander

- Black or African American

- White

Because of limited sample size, Asian, Pacific Islander, Alaskan native and American Indian respondents are not shown as separate categories in this report, but are included in the totals of all tables. These are referred to as "Non-Hispanic other races."

Office of Management and Budget (OMB) guidelines on the classification of race require statistical reports to separate those who reported only one race from the small proportion of the population who reported more than one race. Large data sets such as the U.S. Census, the National Vital Statistics System, and some very large surveys can produce reliable statistics on these respondents who report more than one race. Unfortunately, the NSFG's sample size of 12,571 respondents cannot produce reliable statistics for very small 
subgroups such as respondents who report more than one race, or "multiplerace" respondents. Men and women who reported only one race are classified based on the HISPRACE Recode described previously. All non-Hispanic men and women who reported more than one race are included in the totals of all tables but cannot be shown separately because of insufficient sample sizes. The categories shown in this report are as follows:

Hispanic or Latino

Not Hispanic or Latino:

White, single race

Black or African American, single

race

Interpretation of data by race and Hispanic origin-Hispanic origin and race are associated with a number of indicators of social and economic status. Differences among white, black, and Hispanic men and women in the tables are often related to differences in income, education, (54), access to health care and health insurance, the communities in which they live (55), and other factors.

\section{Metropolitan residence (at} interview)_This variable classifies the location of the respondent's address at the time of interview according to year 2000 Census Bureau population counts and definitions of metropolitan statistical areas set forth by OMB. The code categories are:

$1=$ Central city of one of the 12 largest metropolitan areas (listed below)

$2=$ Central city of any other metropolitan area

$3=$ In one of the 12 largest metropolitan areas, but not the central city

4= In any other metropolitan area, but not the central city

$5=$ Not in a metropolitan area

Categories 3 and 4 are sometimes referred to as "suburbs of metropolitan areas" in the text. Category 5 is further divided in the tables into rural and urban areas, also as defined by the Census Bureau. The 12 largest metropolitan areas (in population size) as of the 2000 census were:

(1) New York-Northern New JerseyLong Island (NY, NJ, CT, PA)
(2) Los Angeles-Riverside-Orange County, CA

(3) Chicago, IL-Gary, IN-Kenosha, WI

(4) Washington, DC-Baltimore, MD

(5) San Francisco-Oakland-San Jose, CA

(6) Philadelphia, PA-Wilmington, DL-Atlantic City, NJ

(7) Boston-Worcester-Lawrence, MA

(8) Detroit-Ann Arbor-Flint, MI

(9) Dallas-Ft Worth, TX

(10) Houston-Galveston-Brazoria, TX

(11) Atlanta, GA

(12) Miami-Ft. Lauderdale, FL

The smallest of these areas, Miami-Ft. Lauderdale, contained about 3.9 million people in 2000; the total population of these 12 areas in the year 2000 was about 97 million people, about one-third of the population of the United States.

Military service-Males 18 years of age and over were asked in CAPI:

"Have you ever been on active duty in the Armed Forces for a period of 6 months or more?"

In this report, data by military service are only shown for males 25-44 years of age because most of those 15-19 are too young to have served in the Armed Forces. Thus, the group that has "never served" would be disproportionately 15-19, and, therefore, younger on average, than those reporting past military service. Data on military service were not collected from females in the NSFG because the NSFG is not large enough to produce reliable estimates of females who have served in the military.

\section{Poverty level at interview} $($ recode $=$ POVERTY $)$ - The poverty level index (or percentage of poverty level as it is labeled in the tables) was calculated by dividing the total family income, as reported in ACASI, by the weighted average threshold income of families whose head of household was under 65 years of age, based on the 2001 poverty levels defined by the U.S. Census Bureau. This definition of poverty status takes into account the number of persons in the family. Total family income includes income from all sources for all members of the respondent's family. For example, for a family of four in 2001, the poverty level was $\$ 18,104$. So, if a family of four had an income of $\$ 40,000$, their poverty level income would be

$(\$ 40,000 / 18,104) \times 100$, or 220 percent.

This respondent would be classified in the category " $150-299$ percent of poverty level."

The tables in this report show data by poverty level income only for those 20-44 years of age at interview. This is because reports of income by teenagers are likely to be less accurate.

For 1,044 of the 12,571 respondents, or 8.3 percent, total family income at the date of the NSFG Cycle 6 interview was not ascertained and was imputed. Imputation procedures are described in a separate report (56).

Region (of residence at interview)_-The REGION recode classifies region of residence at the time of the interview into the four major census regions: Northeast, Midwest, South, and West. These regions are as follows:

Northeast Maine, New Hampshire, Vermont, Massachusetts, Rhode Island, Connecticut, New York, New Jersey, and Pennsylvania

Midwest Ohio, Indiana, Illinois, Michigan, Wisconsin, Minnesota, Iowa, Missouri, North Dakota, South Dakota, Nebraska, and Kansas

South Delaware, Maryland, District of Columbia, Virginia, West Virginia, North Carolina, South Carolina, Georgia, Florida, Kentucky, Tennessee, Alabama, Mississippi, Arkansas, Louisiana, Oklahoma, and Texas

West Montana, Idaho, Wyoming, Colorado, New Mexico, Arizona, Utah, Nevada, Washington, Oregon, California, Alaska, and Hawaii. 


\section{Question wording on HIV risk and related variables, Cycle 6 NSFG and four surveys used for comparison}

\section{Items from Cycle 6 NSFG:}

Number of partners in the past 12 months-For both males and females, this measure was based on the ACASI questions that asked about numbers of opposite-sex partners with whom the respondent had any sexual contact, not limited to vaginal intercourse. The questions below followed a series of questions asking about types of sexual activity.

For females, number of partners in the last 12 months comes from the ACASI (self-administered) file variable PARTS12M_1, which was based on question JF-2:

"Thinking about the last 12 months, that is, since (month/year), how many male sex partners have you had? Please count every partner, even those you had sex with only once."

For males, it comes from the ACASI file variable PARTS12_1, which was based on question KG-2:

"Thinking about the last 12 months, that is, since (month/year), how many female sex partners have you had? Please count every partner, even those you had sex with only once."

Male-to-male sex in the past 12 months-This item is defined for males based on the number of reported male oral or anal sex partners in the past year, item MALPRT12 on the male ACASI file, based on question KJ-2. Male respondents who had reported that they had ever had male sex partners were asked:

"During the last 12 months, that is, since (month/year), how many male sexual partners have you had?"

Women with male sex partners in the past 12 months who had sex with other men-This measure for females only is based on the item BISEXPRT, question JF-3 of the female ACASI questionnaire:

"(Now please think about all of your male sexual partners in the last 12 months, that is since (month/year)).

Have any of your male partners in the last 12 months ever had sex with other males?"

\section{Respondents with at-risk sex} partners in the past year-Risk behavior items were defined for respondents who reported in the past year having sex with injecting drug users, persons known to be HIV infected, and exchanging sex for drugs or money. These are based on a series of ACASI questions that are worded somewhat differently for males and females. The male data are based on items FEMSHT12, JOHNFREQ, PROSTFREQ, HIVFEM12 (questions KG-6 through KG-9):

"In the last 12 months, have you had sex with a female who takes or shoots street drugs using a needle?"

"In the last 12 months, have you given a female money or drugs in exchange for having sex with you?"

"In the last 12 months, has a female given you money or drugs to have sex with her?"

"In the last 12 months, have you had sex with a female who you knew was infected with the AIDS virus?"

For females these data are based on items MALSHT12, PROSTFRQ, JOHNFREQ and HIVMAL12 (questions JF-6 through JF-9):

"In the last 12 months, have you had sex with a male who takes or shoots street drugs using a needle?"

"In the last 12 months, has a male given you money or drugs to have sex with him?"

"In the last 12 months, have you given a male money or drugs to have sex with you?"

"In the last 12 months, have you had sex with a male who you knew was infected with the AIDS virus?"

\section{STD treatment in the past year-}

Throughout this report, the term STD or sexually transmitted disease has been used in referring to the results of the question on whether respondents had been treated for a sexually transmitted disease in the past year. This measure was derived from responses to the item STDTRT12 (question KK-8 for males and question JH-5 for females):

"In the past 12 months, have you been treated or received medication from a doctor or other medical care provider for a sexually transmitted disease like gonorrhea, chlamydia, herpes, or syphilis?"

The term sexually transmitted infection (STI) is preferred to STD by some, because infections may be asymptomatic, and therefore not "disease." Others use the terms STD and STI interchangeably. The term STD has been used here to be consistent with the question wording, which specifically uses the term "disease" and refers to interaction with a health care provider to receive treatment or medication.

Any illicit drug injection in past 12 months-This variable is based on the item INJECT12- question KC-6 on the male questionnaire and question JC-9 on the female questionnaire:

"During the last 12 months, how often have you taken nonprescription drugs using a needle, that is, you took them only for the experience or feeling it caused? This includes 'shooting up' and 'skin-popping.",

Use of crack cocaine-Use of crack cocaine in the past year was measured using the data item CRACK12 derived from the questions KC-5 (male) and JC-8 (female):

"During the last 12 months, how often have you used crack?"

HIV testing (outside of blood donation)-This was based on the item HIVTEST (question HE-2 for females and IF-2 for males):

"(Apart from testing that may have been done with your blood donations,) have you ever had your blood tested for HIV, the virus that causes AIDS?"

\section{Condom use during last sexual} encounter-This was defined for males on last vaginal intercourse (CONDVAG) or during last male-to-male oral or anal intercourse (for males who reported this 
behavior) (CNDLSML), based on questions KE-3 and KJ-3:

"Did you use a condom the last time you had vaginal intercourse with a female?"

"The last time you had oral or anal sex with a male partner, was a condom used?"

Males who reported both male and female partners in the past year were classified as condom users if they used a condom during their last sexual encounter with either male or female partner.

For females, this measure was based on item CONDVAG, from question JD-4:

"Was a condom used the last time you had vaginal intercourse with a male?"

\section{Comparative items from other surveys:}

Crack cocaine use and drug injection in the past year, National Survey of Drug Use and Health (NSDUH)These measures were based on the following items from the 2002 NSDUH. Use of crack is based on questions CK01 and CKLAST3:

The next questions are about 'crack', that is cocaine in rock or chunk form, and not the other forms of cocaine.

"Have you ever, even once, used 'crack'?”

"How long has it been since you last used 'crack'?"

Illicit drug injection in the past year is based on questions asked separately about the injection of heroin, cocaine, methamphetamine, and other stimulants:

\section{HERNEEDL}

"Have you ever, even once, used a needle to inject heroin?"

\section{HRNDLREC}

"How long has it been since you last used a needle to inject heroin?"

\section{COCNEEDL}

"Have you ever, even once, used a needle to inject cocaine?"

\section{CONDLREC}

"How long has it been since you last used a needle to inject cocaine?"

\section{MTHNEEDL}

"Have you ever, even once, used a needle to inject Methamphetamine, Desoxyn, or Methedrine when it was not prescribed for you or that you took only for the experience or feeling it caused?"

\section{MTNDLREC}

"How long has it been since you last used a needle to inject Methamphetamine, Desoxyn, or Methedrine when it was not prescribed for you or that you took only for the experience or feeling it caused?"

\section{OSTNEEDL}

"Have you ever, even once, used a needle to inject any other stimulant/a stimulant when it was not prescribed for you or that you took only for the experience or feeling it caused?"

\section{OSTNLREC}

"How long has it been since you last used a needle to inject (any other stimulant/any stimulant) when it was not prescribed for you or that you took only for the experience or feeling it caused?"

NEDLRECR-Recoded variable based on above items:

"Most recent time used cocaine, heroin, or stimulants with a needle."

Number of sex partners and male-tomale sex in the past year, General Social Survey (GSS)-Estimates were based on data from the combined 200002 GSS. Numbers of past year sex partners is based on the question:

"How many sex partners have you had in the last 12 months?"

Male-to-male sex in the past year was based on responses of males to the following question, which was asked of both sexes:

"Have your partners in the last 12 months been exclusively male, both male and female, or exclusively female?"

Sexually transmitted disease (STD) in past 5 years, from the National Health Interview Survey (NHIS)— This measure was based on question
ADS.160 from the 2002 NHIS:

"The next questions are about other sexually transmitted diseases or STDs. STDs are also known as venereal diseases or VD. Examples of STDs are gonorrhea, chlamydia (CLUH-MIHDEE-UH), syphilis, herpes, and genital warts.

In the past 5 years, have you had an STD other than HIV or AIDS?"

Composite indirect measure of HIV risk behavior, National Health Interview Survey (NHIS)_-This is based on question ADS.150 on the 2002 NHIS:

"Tell me if ANY of these statements is true for YOU. Do NOT tell me WHICH statement or statements are true for you. Just IF ANY of them are.

(a) You have hemophilia and have received clotting factor concentrations.

(b) You are a man who has had sex with other men, even just one time.

(c) You have taken street drugs by needle, even just one time.

(d) You have traded sex for money or drugs, even just one time.

(e) You have tested positive for HIV (the virus that causes AIDS).

(f) You have had sex (even just one time) with someone who would answer yes to any of these statements."

Composite indirect measure of HIV risk, Behavioral Risk Factor Surveillance System (BRFSS)—This measure is based on the item HIVRISK2 from the BRFSS 2002 data set, which is derived from question 17.08:

"I'm going to read you a list. When I'm done, please tell me if any of the situations apply to you. You don't need to tell me which one. You have used intravenous drugs in the past year. You have been treated for a sexually transmitted or venereal disease in the past year. You have given or received money or drugs in exchange for sex in the past year. You had anal sex without a condom in the past year. Do any of these situations apply to you?" 


\section{Acknowledgments}

The Cycle 6 (2002) National Survey of Family Growth (NSFG) was conducted by the National Center for Health Statistics (NCHS) with the support and assistance of a number of other organizations and individuals. Interviewing and other tasks were carried out by the University of Michigan's Institute for Social Research, under a contract with NCHS. The Cycle 6 NSFG was jointly planned and funded by the following programs and agencies of the U.S. Department of Health and Human Services:

- The National Institute of Child Health and Human Development (NICHD)

- The Office of Population Affairs

- The CDC's National Center for Health Statistics (NCHS/CDC)

- The CDC's National Center for HIV, STD, and TB Prevention

- The CDC's Division of Reproductive Health

- The CDC's Office of Women's Health

- The Office of Planning, Research, and Evaluation of the Administration for Children and Families (ACF)

- The Children's Bureau of the ACF

- The Office of the Assistant Secretary for Planning and Evaluation (OASPE)

NCHS gratefully acknowledges the contributions of these programs and agencies and all others who assisted in designing and carrying out the NSFG. This report was prepared under the general direction of Charles J. Rothwell, Director of the Division of Vital Statistics and Stephanie J. Ventura, Chief of the Reproductive Statistics Branch, Division of Vital Statistics. The authors gratefully acknowledge the peer review of an earlier draft of this report by Geraldine MacQuillan, Ph.D., NCHS. Karen E. Davis, M.A., and Lester R. Curtin, Ph.D., NCHS provided guidance on the technical appendix on "Computing confidence intervals from standard errors." The authors also gratefully acknowledge the assistance of Yashodhara Patel. This report was edited by Gail V. Johnson of the Information Design and Publishing Staff, Office of Information Services, NCHS; typesetting was done by Annette F. Holman, and graphics were produced by Odell Eldridge, Contractor, of the Division of CoCHIS/NCHM/Division of Creative Services.

\section{Suggested citation}

Anderson JE, Mosher WD, Chandra A. Measuring HIV risk in the U.S. population aged 15-44: Results from Cycle 6 (2002) of the National Survey of Family Growth. Advance data from vital and health statistics; no 377. Hyattsville, MD: National Center for Health Statistics. 2006.

\section{Copyright information}

All material appearing in this report is in the public domain and may be reproduced or copied without permission; citation as to source, however, is appreciated.
National Center for Health Statistics

Director

Edward J. Sondik, Ph.D.

Acting Co-Deputy Directors Jennifer H. Madans, Ph.D. Michael H. Sadagursky

\section{U.S. DEPARTMENT OF \\ HEALTH \& HUMAN SERVICES}

Centers for Disease Control and Prevention

National Center for Health Statistics

3311 Toledo Road

Hyattsville, MD 20782

OFFICIAL BUSINESS

PENALTY FOR PRIVATE USE, \$300

To receive this publication regularly, contact the National Center for Health Statistics by calling 1-866-441-NCHS (6247)

E-mail: nchsquery@cdc.gov

Internet: www.cdc.gov/nchs

06-0145 (10/06)

CS106397

T26780

DHHS Publication No. (PHS) 2007-1250 